\title{
Audyt efektywności kosztowej inwestycji w infrastrukturę drogową w powiatach województwa mazowieckiego
}

\author{
Natalia Jankowska, Piotr Modzelewski
}

\section{STRESZCZENIE}

Celem artykułu było sprawdzenie, czy możliwe jest przeprowadzenie wstępnego audytu efektywnościowego w zakresie pomiaru efektywności kosztowej w obszarze budowy infrastruktury drogowej przez samorządy lokalne, na podstawie informacji publicznej powszechnie dostępnej, bez konieczności zwracania się o dostęp do danych. Audyt efektywnościowy jest instrumentem, który pozwala m.in. na pomiar efektywności kosztowej i dokonywanie porównań pomiędzy jednostkami samorządowymi w zakresie realizacji poszczególnych szczegółowych rodzajów zadań. Przeprowadzenie takiego audytu w pełnej postaci jest jednak zwykle dość czasochłonne, skomplikowane i wymagałoby zaangażowania zespołów eksperckich, którzy musieliby pozyskać informacje wewnętrzne z poszczególnych jednostek samorządu terytorialnego (JST) na temat kosztów realizowanych inwestycji. Jednakże już wstępne porównania $\mathrm{w}$ zakresie wydatków publicznych na podobne lub takie same przedsięwzięcia mogą być bardzo przydatne zarówno w bieżącej pracy samorządów lokalnych, jak i niezwykle użyteczne dla obywateli, włączających się w procesy demokratyczne na poziomie lokalnym. Zasadne byłoby zatem postulowanie, aby już na poziomie powszechnie dostępnej informacji publicznej, niewymagającej specjalnego, zwykle każdorazowego ubiegania się o dostęp do danych, możliwe było dokonywanie porównań pomiędzy np. inwestycjami samorządowymi. Jednakże kluczem i warunkiem koniecznym do dokonania chociażby wstępnego audytu efektywnościowego jest zapewnienie porównywalności przy pomiarze efektywności kosztowej poszczególnych inwestycji. Taki wstępny audyt w zakresie kosztu jednostkowego realizowanych inwestycji dostępny powszechnie dla obywateli czy samorządowców może być następnie traktowany jako punkt wyjścia do dyskusji na forum publicznym, czy też dokonania dalszej, bardziej szczegółowej oceny zasadności dokonywanych inwestycji lub też zestawiania danych nt. efektywności kosztowej z miarami skuteczności wydatkowania środków publicznych.

Słowa kluczowe: audyt efektywnościowy, efektywność kosztowa, samorząd terytorialny

\section{WSTĘP}

W gospodarkach krajów rozwiniętych sektor publiczny pełni zdecydowanie ważną rolę. Oczekiwania obywateli mogą powodować presję na zwiększanie efektywności gospodarowania środkami publicznymi. Jednym ze znaczących wyzwań podejmowanych problemów stała się efektywność kosztowa sektora publicznego, która w niniejszym artykule jest rozważana jako relacja nakładów i wyników ${ }^{1}$. Wzrost oczekiwań społeczności lokalnych wymusza postęp w sektorze publicznym, ale również konieczność zwiększania dostępności i porównywalności danych związanych z wydatkowaniem środków publicznych.

\footnotetext{
${ }^{1}$ Odwołania do bardziej szczegółowych rozważań nt. efektywności i definicji [Modzelewski 2009].
} 
W latach 80. XX w. rozpoczęły się reformy w nurcie Nowego Zarządzania Publicznego (New Public Management - NPM) równolegle w Wielkiej Brytanii i w USA [Politt, Bouckaert 2011], które w początkowej swojej fazie nakierowane były na wzrost efektywności funkcjonowania sektora publicznego i dostarczania odpowiedniej „wartości za pieniądze” (value for money), by następnie zwrócić się w stronę jakości i skuteczności sektora publicznego [Modzelewski 2009]. Należy jednak zwrócić uwagę, iż pomiar efektywności kosztowej, rozumianej w uproszczeniu jako relacja nakładów do wyników, nie przestał być aktualny i w zależności od stopnia skomplikowania usług publicznych nadal jest ważnym elementem ewaluacji sektora publicznego. Koncepcje w nurcie NPM dotarły również do Polski, przy czym nadal w wielu obszarach sektora publicznego, gdzie możliwe i zasadne byłoby przeprowadzanie oceny efektywności kosztowej dostarczania usług publicznych, nie jest to czynione. W świetle Ustawy o finansach publicznych pomiar efektywności jest obligatoryjny w ramach realizacji kontroli zarządczej [UFP, art. 67, 68], ale nie jest jedynym kryterium decyzyjnym. Oprócz zwiększenia efektywności działań sektora publicznego kontrola zarządcza wskazuje na konieczność zapewnienia skuteczności w sektorze publicznym, jak również na konieczność zapewnienia gospodarności, czyli wprowadza kryterium „oszczędności”. Ustawa o finansach publicznych (UFP) zwraca uwagę, że wydatkowanie środków publicznych powinno odbywać się „z zachowaniem zasad uzyskania najlepszych efektów z danych nakładów” [UFP, art. 162 ust. 3], co jest właśnie emanacją takiego rodzaju efektywności jak ta kosztowa². Oczywiście efektywność kosztowa budowy, np. drogi publicznej, nie może być jedynym kryterium decyzyjnym w ramach przeprowadzania kontroli zarządczej czy w ramach podejmowania decyzji na poziomie planowania, budżetowania, finansowania i realizacji, gdyż każdorazowo powinna być ona zestawiana ze skutecznością zarówno na poziomie rezultatów w postaci np. skrócenia czasu podróży dla odpowiednio dużej kohorty użytkowników, jak też na poziomie oddziaływań społecznych, gospodarczych. Równie niezbędne, do oceny inwestycji drogowej, może być kryterium dostępności komunikacyjnej lub konieczność zapewnienia odpowiedniej sieci komunikacyjnej w wymiarze wojewódzkim bądź ogólnopolskim. Jednakże wiedza dotycząca budowy $1 \mathrm{~km}$ drogi jest niezbędna, aby ocenić czy wydatkowanie środków było zgodne z kryterium gospodarności i rozważanie to nie powinno być pominięte, nawet, jeśli istnieją obiektywne powody, dla których ten koszt był znacząco wyższy. Uzasadnienie tego kosztu powinno leżeć w gestii władz samorządowych i może być

\footnotetext{
${ }^{2} \mathrm{Z}$ tego też powodu w niniejszym artykule skupiono się na szczególnym rodzaju efektywności produkcyjnej, jaką jest efektywność kosztowa, a pominięto dyskusję nad takimi rodzajami efektywności jak alokacyjna, dystrybucyjna czy dynamiczna [zob. szerzej: Andrews, Entwistle 2014]. Przyjęto również najprostszą definicję efektywności kosztowej w postaci relacji nakładów do wyników, która to definicja jest zasadna w przypadku rozważania jednego nakładu i jednego wyniku, ale może być również dla uproszczenia stosowana $w$ odniesieniu do analiz adresowanych do szerszego grona odbiorców, np. obywateli poszczególnych samorządów lokalnych oraz osób potrzebujących m.in. wstępnych informacji przekrojowych nt. kosztu jednostkowego inwestycji realizowanych przez JST, np. kosztu budowy $1 \mathrm{~km}$ infrastruktury drogowej. To uproszczenie wymaga jednak sprowadzenia inwestycji do wspólnego mianownika i porównywanie inwestycji m.in. o podobnych parametrach i cechach funkcjonalnych.
} 
dokonane albo za pomocą wskazania wartości szeregu mierników pomocniczych (np. związanych z ukształtowaniem terenu, warunkami melioracyjnymi, koniecznością podłączenia do istniejącej infrastruktury drogowej), albo za pomocą opisu jakościowego. Jeśli jednak nie jest znany nawet koszt jednostkowy i brak jest jakichkolwiek punktów odniesienia do inwestycji uprzednio wykonanych, również $w$ innych jednostkach samorządowych, trudno jest racjonalnie dyskutować o kolejnych inwestycjach, czy też planować wydatki publiczne w perspektywie wieloletniej.

W wielu przypadkach, na poziomie samorządowym, poprzestaje się na dokonywaniu audytu wiarygodności i zgodności, jednak zasadne jest stosowanie również audytu efektywnościowego [Bartoszewicz 2015a], który wspiera decydentów jednostki sektora publicznego w realizacji celów i zadań [Szołno 2016]. Istotą audytu efektywnościowego jest m.in. właśnie pomiar efektywności kosztowej [Nita 2015].

Zdaniem Autorów niniejszego artykułu występują zasadnicze wyzwania związane z pomiarem efektywności kosztowej, m.in. w samorządach terytorialnych w Polsce, z uwagi na brak odpowiednio przygotowanych danych statystycznych dostępnych bez konieczności każdorazowego występowania o takie dane. Krajowa statystyka publiczna nie jest przygotowana do dostarczenia pełnych informacji decydentom podejmującym decyzje o wydatkowaniu środków publicznych. Poważnym wyzwaniem jest takie prezentowanie informacji w statystyce publicznej, które umożliwiałoby dokonywanie porównań pomiędzy jednostkami samorządu terytorialnego. W związku z tym, przeprowadzenie nawet „wstępnego audytu efektywnościowego", czy też inaczej mówiąc wstępnych badań porównawczych, takich, które mogą być dokonane na podstawie powszechnie dostępnych danych, zwłaszcza w zakresie pomiaru jednostkowych kosztów inwestycji, jest utrudnione. Zgodnie z powyższym, Autorzy artykułu podjęli się sprawdzenia, czy możliwy jest pomiar efektywności kosztowej na przykładzie wybranego obszaru interwencji ze środków publicznych. Celem artykułu jest zweryfikowanie, czy możliwe jest przeprowadzenie wstępnego audytu efektywnościowego w zakresie pomiaru kosztu jednostkowego w obszarze budowy infrastruktury drogowej przez samorządy lokalne na podstawie danych powszechnie dostępnych w informacji publicznej bez konieczności występowania o takie dane. Główna hipoteza badawcza artykułu brzmi: w systemie wydatkowania środków publicznych na infrastrukturę drogową na poziomie samorządowym możliwe jest przeprowadzenie wstępnego audytu efektywnościowego w zakresie pomiaru efektywności kosztowej na podstawie dostępnych danych z systemu statystyki publicznej. Cel pracy został osiągnięty na podstawie badania empirycznego. Badaniem empirycznym objęto powiaty z terenu województwa mazowieckiego, z wyłączeniem miast na prawach powiatu, z uwagi na dążenie do zapewnienia porównywalności badanych samorządów terytorialnych. Przyjęto założenie, że cel pracy będzie realizowany na podstawie kryterium kosztu uzyskania informacji (od najniższej do najwyższej ilości czasu niezbędnego do pozyskania informacji), zatem badanie empiryczne wymagało przyjęcia podejścia wielostopniowego. Rozpoczęto rozważania od ogólnego oglądu efektywności kosztowej wydatkowania środków publicznych na infrastrukturę drogowa, a następnie zawężono badanie tylko do tych inwestycji drogowych, które były dofinansowane ze środków 
strukturalnych Unii Europejskiej. Z uwagi na dostępność danych (w związku z zakresem danych w bazie Krajowego Systemu Informatycznego SIMIK), na ostatnim etapie Autorzy podjęli się weryfikacji, czy możliwie jest przeprowadzenie wstępnego audytu efektywnościowego w zakresie pomiaru efektywności kosztowej na podstawie danych z lat 2007-2015 w odniesieniu do tych inwestycji drogowych, które były dofinansowane ze środków strukturalnych UE. Dla uproszczenia wywodu przyjęto, iż nie będą uwzględniane wydatki na infrastrukturę drogową poniesione przed rozpoczęciem badanego okresu, jak również założono pominięcie efektów związanych z wytworzeniem "produktów” (kilometrów infrastruktury drogowej) w kolejnych latach niż dokonywane wydatki, uznając zwłaszcza tę drugą kategorię za pomijalna, z uwagi na sposób sporządzania i podpisywania protokołów zdawczo-odbiorczych podczas wykonywania inwestycji oraz z reguły stosowanie zasady kasowej rachunkowości przy realizacji tego typu inwestycji. Z kolei koszty prac przygotowawczych związanych z uchwaleniem wieloletniego planu inwestycyjnego, czy też przygotowaniem danej inwestycji, z jednej strony są niezwiązane z konkretnym przetargiem już na wykonanie inwestycji (a to jest przedmiotem porównań w niniejszym artykule), a z drugiej strony koszty tych prac stanowią znikomy procent wartości inwestycji ogółem oraz muszą być ponoszone w przypadku wszystkich inwestycji, stąd nie tłumaczyłyby znaczącego odsetka zmienności kosztu jednostkowego wybudowania infrastruktury drogowej danego typu.

W niniejszym artykule wykorzystano następujące metody badawcze: analizę danych finansowych samorządów lokalnych, analizę krytyczną dokumentów takich jak: Specyfikacja istotnych warunków zamówienia (SIWZ) projektów związanych z budowa/przebudową dróg lokalnych badanych jednostek, projekty umów w postaci załączników do SIWZ dotyczące projektów realizujących budowę/przebudowę dróg lokalnych. Źródłami danych finansowych były: Bank Danych Lokalnych Głównego Urzędu Statystycznego (BDL), Krajowy System Informatyczny SIMIK (KSI SIMIK), biuletyny informacyjne zarówno powiatów, jak i gmin; oficjalne witryny internetowe powiatów i gmin oraz ogólnie dostępne zasoby internetowe.

\section{Audyt efektywnościowy jako narzędzie oceny systemu kontroli zarządczej}

Zgodnie z obowiązującymi standardami kontroli zarządczej, której działania nakierowane są na osiągnięcie celu, zaistniała potrzeba wskazania metod służących do pomiaru realizacji tego celu [Nita 2015]. Skuteczność i efektywność to podstawowe kryteria służące do oceny administracji publicznej, jednak niemniej ważne są metody, które umożliwiają zbadanie tych kryteriów, co spowodowało wyodrębnienie mierników produktu, rezultatu i oddziaływania [Politt, Bouckaert 2011; Szołno 2016]. Dokonując oceny efektywności kosztowej na podstawie mierników nakładów i produktów (wyników) można natrafić na pewne ograniczenia. Ustalenia poziomu efektywności kosztowej łatwo dokonać, jeśli nakłady i efekty mają jednakowe wymiary lub jest możliwe ich przedstawienie we wspólnej jednostce. Jeśli natomiast nie jest możliwe wyrażenie wielkości nakładów i efektów w jednej jednostce po- 
miaru, badanie efektywności realizacji poszczególnych zadań przez JST staje się kłopotliwe. Istotność pozyskania tego typu informacji została również zauważona w badaniu przeprowadzonym przez Kancelarię Prezesa Rady Ministrów [KPRM 2011], zaś pewne wskazówki dokonywania audytu efektywnościowego udostępniło Ministerstwo Finansów [MF 2017]. Audyt efektywnościowy został zdefiniowany jako „systematyczny, celowy i zorganizowany proces rzetelnej polityki, programów i projektów publicznych oraz oceny bieżącego funkcjonowania jednostek sektora publicznego w oparciu o kryteria gospodarności, efektywności i skuteczności ich działania." [Bartoszewicz 2015b]. W związku z powyższymi opracowaniami zdecydowano się na sprawdzenie, czy jest możliwe przeprowadzenie chociażby wstępnego audytu efektywnościowego w zakresie pomiaru efektywności kosztowej, na podstawie dostępnych danych statystycznych i innych w ogólnodostępnej informacji publicznej. Autorzy w niniejszym tekście abstrahuja co prawda, od rozważań nt. skuteczności wydatkowania środków publicznych, jednak wynika to z faktu, iż efektywność kosztowa może być zestawiana ze skutecznością, jeżeli nastąpiło wyliczenie tej pierwszej (zaś najczęściej jest to pomijane w rozważaniach nad samorządem lokalnym m.in. z uwagi na trudność pomiaru i dokonywania porównań na poziomie kosztu jednostkowego danego rodzaju inwestycji). To właśnie wtedy możliwa jest dyskusja o zasadności wydatków i argumentowanie, dlaczego jedne inwestycje są tańsze, a inne droższe. Możliwe jest również dołączenie do analizy mierników pomocniczych czy też opisu jakościowego. Z doświadczeń Autorów wynika jednak, iż to właśnie pomiar efektywności kosztowej przysparza najwięcej problemów na poziomie samorządowym i staje się blokadą do przeprowadzenia miarodajnego i pełnego audytu efektywnościowego. Zatem, jeśli nie jest możliwe dokonanie nawet „wstępnego audytu efektywnościowego" w zakresie porównania kosztu jednostkowego zrealizowanych, podobnych inwestycji, to tym bardziej nie byłoby możliwe dokonanie tego audytu w pełnej postaci.

\section{Weryfikacja możliwości stosowania wstępnego audytu efektywnościowego w obszarze transportu w powiatach województwa mazowieckiego}

W pierwszym etapie badania zdecydowano się na przedstawienie poziomu wielkości wydatków inwestycyjnych na drogi lokalne w powiatach województwa mazowieckiego. Następnie skupiono się na przedstawieniu zależności pomiędzy wydatkami inwestycyjnym na drogi lokalne powiatów wojewódzwa mazowieckiego w latach 2012-2015 a wielkością przyrostu dróg lokalnych w danym powiecie województwa mazowieckiego. W osiągnięciu wspomnianego celu pomocna stała się baza danych BDL.

Wartości wydatków inwestycyjnych na drogi lokalne na terenie danego powiatu województwa mazowieckiego uzyskano sumując wartości wydatków inwestycyjnych na drogi gminne i powiatowe w okresie od 2012 r. do 2015 r. (ryc. 1), co wynikało z dostępności danych w bazie BDL. 


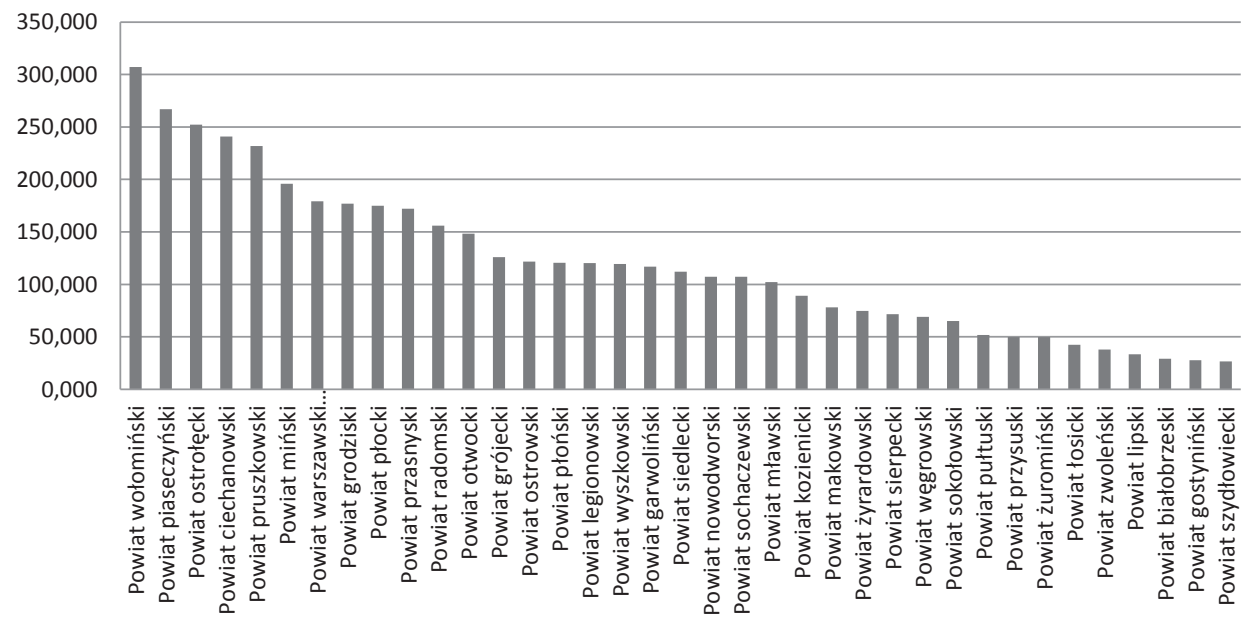

Ryc. 1. Wydatki inwestycyjne na drogi lokalne powiatów województwa mazowieckiego w ujęciu bezwzględnym, w podziale na powiaty (w mln zł), w latach 2012-2015

Źródło: opracowanie własne na podstawie BDL

Najwyższą pozycję, pod względem wydatków inwestycyjnych per capita, zajmuje powiat przasnyski z wynikiem 3233,16 zł na głowę mieszkańca, choć wartość wydatków w ujęciu bezwzględnym nie jest najwyższa - ponad $172 \mathrm{mln}$ zł. Powodem tego jest m.in. mała liczba ludności zamieszkującej ten teren - nieco ponad 53 tys. osób. Najwyższą pozycję wydatków w ujeciu bezwzględnym zajmuje powiat wołomiński - ponad $307 \mathrm{mln}$ zł. W ujęciu per capita powiat ten zajmuje dopiero 19. pozycję, co jest spowodowane m.in. wysoką liczbą ludności na jego terenie.

Można przypuszczać, że przy wysokim poziomie wydatków inwestycyjnych na drogi lokalne można liczyć na wysoki przyrost dróg lokalnych w poszczególnych powiatach, jednak konieczne było poddanie tego weryfikacji empirycznej. Informacje o wartości zmiennej - przyrost dróg lokalnych powiatów województwa mazowieckiego również uzyskano z bazy BDL, gdzie z dziedziny Transport i łączność, wybrano drogi powiatowe i gminne. Dane prezentowane są w kilometrach. Wartość przyrostu dróg lokalnych obliczono odejmując wartości z 2007 r. od wartości z 2015 r.

Na rycinie 2 została przedstawiona zależność pomiędzy wydatkami inwestycyjnymi na drogi lokalne powiatów województwa mazowieckiego w latach 2012-2015 a przyrostem dróg lokalnych $\mathrm{w}$ danym powiecie. Wyodrębniono 4 podstawowe typy powiatów: typ I- powiaty o wysokich wydatkach inwestycyjnych i wysokim poziomie przyrostu dróg, typ II- powiaty o wysokich wydatkach inwestycyjnych i niskim poziomie przyrostu dróg, typ III - powiaty o niskich wydatkach inwestycyjnych i niskim poziomie przyrostu dróg, typ IV- powiaty o niskich wydatkach inwestycyjnych i wysokim poziomie przyrostu dróg.

(Na wykresie zostały oznaczone powiaty, które rozpatrywano w dalszej analizie) 


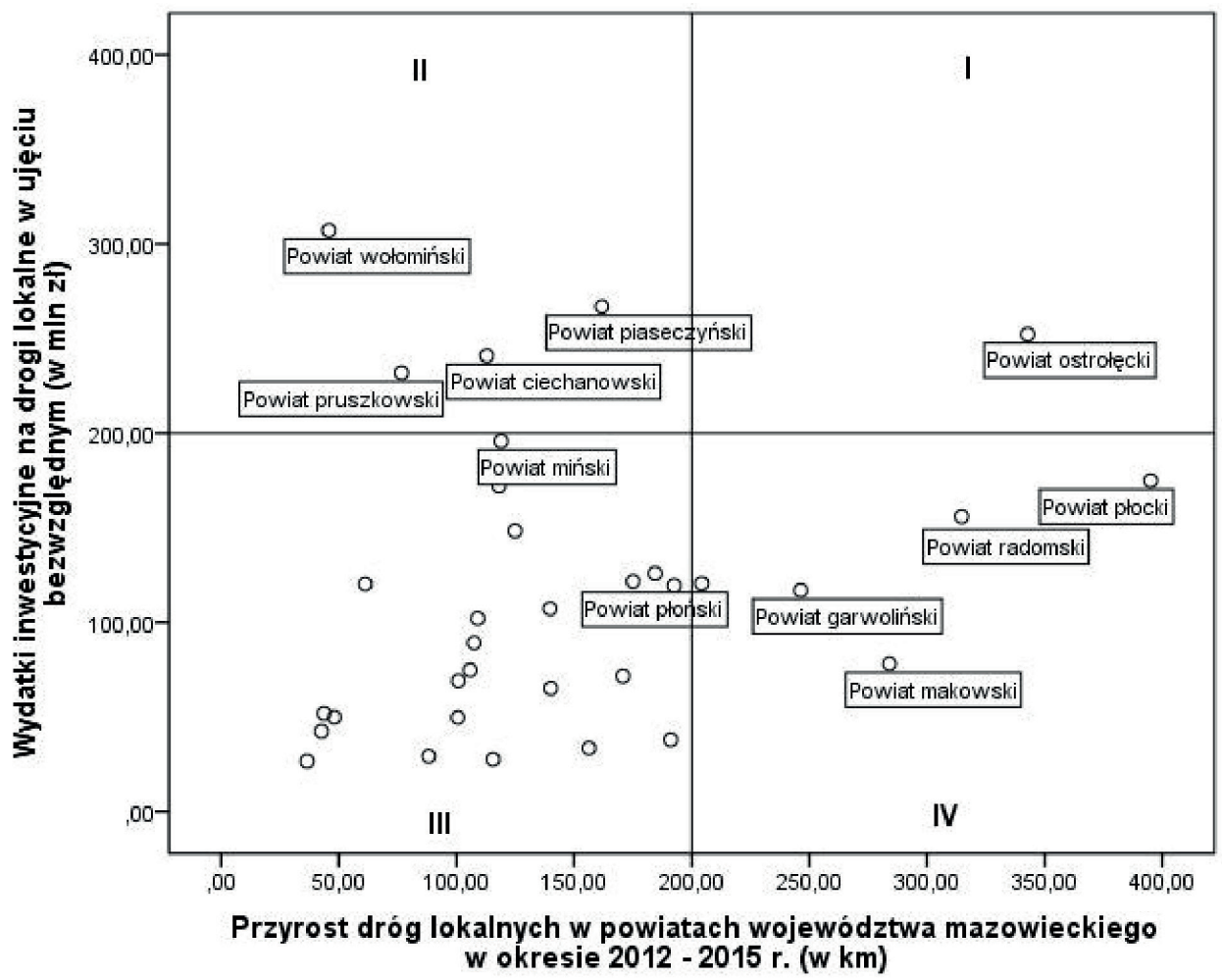

Ryc. 2. Zależność pomiędzy wydatkami inwestycyjnymi na drogi powiatowe i gminne w ujęciu bezwzględnym (w mln zł) a przyrostem dróg lokalnych (w km), w latach 2007-2015

Źródło: opracowanie własne na podstawie bazy danych BDL

Najliczniejszą grupą okazała się grupa III, w której znajduje się 73\% populacji badanych powiatów. Oznacza to, że powiaty znajdujące się w tej ćwiartce wykazują niski poziom wydatków inwestycyjnych na drogi lokalne względem niskiego przyrostu dróg lokalnych w okresie od 2007-2015. Kolejna grupa, z 14\% udziałem populacji to grupa IV. Charakterystyką grupy jest względnie wysoki poziom przyrostu dróg w porównaniu z niskim poziomem wydatków inwestycyjnych w tej dziedzinie. Do opisanej populacji należą powiaty makowski, garwoliński, radomski i płocki. Kolejną grupą jest grupa II, gdzie znajduje się 11\% całej populacji. Grupę tę charakteryzuje względnie mały przyrost dróg do wysokiego poziomu wydatków inwestycyjnych. Ostatnia grupa I, liczącą $2 \%$ populacji, to powiaty, które inwestowały dużą pulę pieniędzy w budowę dróg lokalnych, co przełożyło się na wysoki przyrost tychże dróg.

To, że wydatki inwestycyjne na drogi lokalne nie były związane tylko z budową nowej drogi, jest ważnym wnioskiem wynikającym z powyższego etapu rozważań, jak również ma wpływ na dalszą procedurę badawczą. Zgodnie z wyjaśnieniami Ministerstwa Finansów do ulepszenia środków trwałych zalicza się wydatki na ich: przebudowę, czyli zmianę (poprawienie) istniejącego stanu środków trwałych na inny; rozbudowę, tj. powiększenie (roz- 
szerzenie) składników majątkowych, w szczególności zaś budynków i budowli, linii technologicznych, infrastruktury drogowej itp.; rekonstrukcję, tj. odtworzenie (odbudowanie) zużytych całkowicie lub częściowo składników majątkowych; adaptację, tj. przystosowanie (przerobienie) składnika majątkowego do wykorzystania go w innym celu niż wskazywało jego pierwotne przeznaczenie, albo nadanie temu składnikowi nowych cech użytkowych; modernizację, tj. unowocześnienie środków trwałych. W związku z powyższym, można wnioskować, że wydatki inwestycyjne na projekty dotyczące infrastruktury drogowej były związane nie tylko z budową dróg, ale także ich modernizacją czy rozbudową.

Można więc wyciągnąć wniosek, iż zależności przedstawione na rycinie 2 są niewystarczające do pomiaru efektywności kosztowej. Tym samym, na podstawie danych z bazy BDL nie jest możliwe sprawdzenie, czy wydatki inwestycyjne były związane z budowa, odbudową modernizacją czy przebudową dróg.

Następnie dokonano bardziej szczegółowych porównań w zakresie dążenia do ustalenia kosztu jednostkowego budowy jednego kilometra infrastruktury drogowej w wybranych powiatach. W związku z tym konieczne było zadbanie o zapewnienie porównywalności wybranych do dalszej analizy powiatów województwa mazowieckiego, gdyż różnią się one od siebie pod wieloma względami. Część z nich, jak zostało wspomniane, ma już gęstą siatkę dróg, więc wydatki inwestycyjne będą raczej kierowane na ich modernizację. Niektóre powiaty województwa mazowieckiego mają na swoim terenie Kampinoski Park Narodowy lub parki krajobrazowe, które wręcz uniemożliwiają budowę nowych dróg lub budowa nowej drogi mogłaby okazać się niezwykle kosztowna. Zdecydowano się na pogrupowanie wszystkich powiatów względem ich „podobieństwa”. Głównymi zmiennymi, które wzięto pod uwagę w grupowaniu powiatów były: gęstość zaludnienia, wielkość powierzchni terenu, dotychczasowa siatka dróg na danym terenie, występowanie parków narodowych/krajobrazowych oraz informacja, czy dany powiat jest terenem zalewowym. Powyższe zmienne umożliwiły podzielenie powiatów na pięć grup. Główną zmienna, która decydowała o przynależności do danej grupy była gęstość zaludnienia (tabela 1).

Pierwsza grupa odznacza się najniższą gęstością zaludnienia, ze średnią wartością wynoszącą 48 osób na $1 \mathrm{~km}^{2}$. Największy przyrost dróg w tej grupie osiąga powiat makowski z wynikiem 284 km. Długość dróg w 2007 r. w tym powiecie wynosiła 525,3km, zaś w 2015 sięga już wielkości 809,3 km. Z ryciny 2 można odczytać, że powiat makowski znajdował się w IV ćwiartce, którą charakteryzowały niskie wydatki inwestycyjne i wysoki poziom przyrostu dróg. Drugie miejsce w tym zestawieniu zajmuje powiat lipski, który zwiększył ilość km drogi na $1 \mathrm{~km}^{2}$ powierzchni o 0,2. Dwa ostanie miejsca, pod względem wielkości przyrostu dróg, zajmują powiat przysuski i łosicki, z wynikiem odpowiednio 48,1 km i 42,6 km. W obydwu powiatach gęstość zaludnienia na $1 \mathrm{~km}^{2}$ jest poniżej średniej wartości. Z pozostałych zmiennych w tabeli wynika, że na terenie powiatu łosickiego znajduje się Park Krajobrazowy Podlaski Przełom Bugu. Można przypuszczać, że zmienna ta determinuje niski poziom przyrostu dróg. Podobna sytuacja jest w powiecie przysuskim, który w większości pokrywają lasy i obszary chronionego krajobrazu [Strzelecki 2013, s. 20]. Interesujące, do dalszej analizy, stają się powiaty węgrowski i żuromiński, które mają zbliżone wartości przyrostu dróg, odpowiednio $100,8 \mathrm{~km}$ i $100,6 \mathrm{~km}$. 
Tabela 1. Podział powiatów województwa mazowieckiego na grupy pod względem zdefiniowanych zmiennych

\begin{tabular}{|c|c|c|c|c|c|c|c|c|c|c|c|c|}
\hline$\stackrel{\dot{a}}{\Omega}$ & 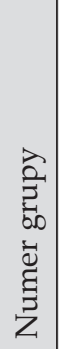 & $\begin{array}{l}\frac{1}{0} \\
\frac{\pi}{3} \\
0 \\
0\end{array}$ & 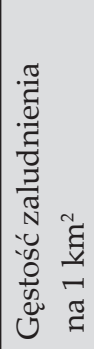 & 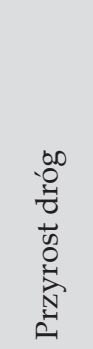 & 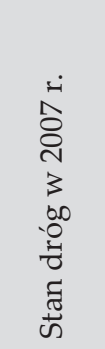 & 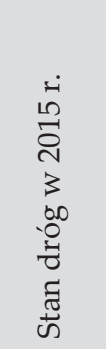 & 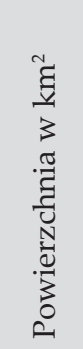 & 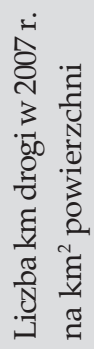 & 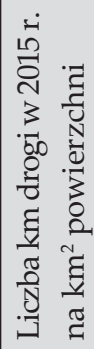 & 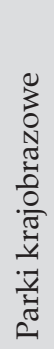 & 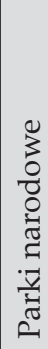 & 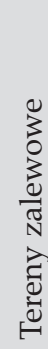 \\
\hline 1. & 1 & białobrzeski & 53 & 88,2 & 428,8 & 517,0 & 639 & 0,70 & 0,80 & - & - & + \\
\hline 2. & 1 & lipski & 47 & 156,3 & 433,8 & 590,1 & 740 & 0,60 & 0,80 & - & - & - \\
\hline 3. & 1 & łosicki & 41 & 42,6 & 456,5 & 499,1 & 772 & 0,59 & 0,65 & + & - & - \\
\hline 4. & 1 & makowski & 43 & 284,0 & 525,3 & 809,3 & 1065 & 0,50 & 0,80 & - & - & + \\
\hline 5. & 1 & przasnyski & 44 & 118,1 & 649,0 & 767,1 & 1219 & 0,50 & 0,60 & - & - & - \\
\hline 6. & 1 & przysuski & 53 & 48,1 & 461,8 & 509,9 & 801 & 0,58 & 0,64 & - & - & - \\
\hline 7. & 1 & sokołowski & 49 & 140,1 & 625,3 & 765,4 & 1131 & 0,60 & 0,70 & + & - & - \\
\hline 8. & 1 & węgrowski & 55 & 100,8 & 559,3 & 660,1 & 1221 & 0,46 & 0,54 & + & - & - \\
\hline 9. & 1 & żuromiński & 49 & 100,6 & 464,8 & 565,4 & 807 & 0,60 & 0,70 & + & - & - \\
\hline 10. & 2 & kozienicki & 67 & 107,5 & 483,2 & 590,7 & 916 & 0,50 & 0,60 & + & - & - \\
\hline 11. & 2 & mławski & 62 & 109,0 & 806,1 & 915,1 & 1182 & 0,70 & 0,80 & - & - & - \\
\hline 12. & 2 & ostrowski & 61 & 175,0 & 676,7 & 851,7 & 1218 & 0,60 & 0,70 & + & - & + \\
\hline 13. & 2 & płoński & 64 & 204,2 & 1043,8 & 1248,0 & 1380 & 0,80 & 0,90 & - & - & - \\
\hline 14. & 2 & pułtuski & 62 & 43,7 & 667,3 & 711,0 & 827 & 0,80 & 0,90 & + & - & + \\
\hline 15. & 2 & sierpecki & 62 & 170,7 & 512,8 & 683,5 & 852 & 0,60 & 0,80 & - & - & - \\
\hline 16. & 2 & zwoleński & 64 & 191,0 & 345,8 & 536,8 & 573 & 0,60 & 0,90 & + & - & - \\
\hline 17. & 3 & garwoliński & 85 & 246,3 & 811,5 & 1057,8 & 1285 & 0,60 & 0,80 & - & - & - \\
\hline 18. & 3 & gostyniński & 75 & 115,5 & 398,3 & 513,8 & 615 & 0,60 & 0,80 & + & - & - \\
\hline 19. & 3 & grójecki & 78 & 184,4 & 943,2 & 1127,6 & 1268 & 0,70 & 0,90 & - & - & + \\
\hline 20. & 3 & nowodworski & 113 & 139,8 & 462,4 & 602,2 & 695 & 0,70 & 0,90 & - & + & + \\
\hline 21. & 3 & sochaczewski & 116 & 171,0 & 559,9 & 730,9 & 735 & 0,80 & 1,00 & - & + & + \\
\hline 22. & 3 & szydłowiecki & 89 & 36,5 & 347,2 & 383,7 & 452 & 0,77 & 0,85 & - & - & - \\
\hline 23. & 3 & wyszkowski & 84 & 192,5 & 505,7 & 698,2 & 876 & 0,60 & 0,80 & - & - & + \\
\hline 24. & 4 & grodziski & 247 & 127,4 & 325,4 & 452,8 & 367 & 0,90 & 1,20 & - & - & - \\
\hline 25. & 4 & legionowski & 290 & 61,2 & 347,3 & 408,5 & 390 & 0,90 & 1,00 & - & - & + \\
\hline 26. & 4 & miński & 130 & 119,0 & 791,9 & 910,9 & 1164 & 0,70 & 0,80 & + & - & - \\
\hline 27. & 4 & otwocki & 200 & 124,9 & 410,4 & 535,3 & 616 & 0,70 & 0,90 & + & - & - \\
\hline
\end{tabular}




\begin{tabular}{|c|c|c|c|c|c|c|c|c|c|c|c|c|}
\hline$\stackrel{\dot{\theta}}{1}$ & 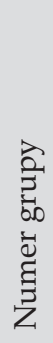 & $\begin{array}{l}\frac{1}{\frac{\pi}{3}} \\
\frac{1}{3} \\
0\end{array}$ & 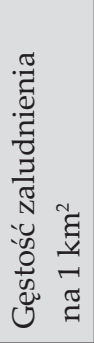 & 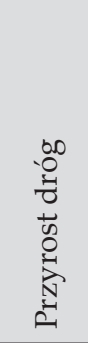 & 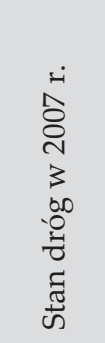 & 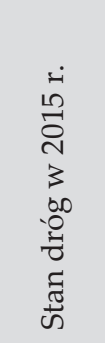 & 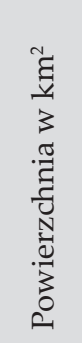 & 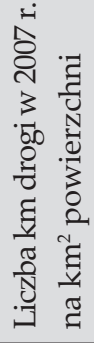 & 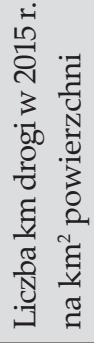 & 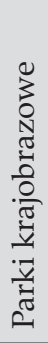 & 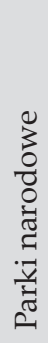 & 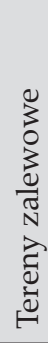 \\
\hline 28. & 4 & piaseczyński & 285 & 161,8 & 636,0 & 797,8 & 621 & 1,0 & 1,3 & + & - & - \\
\hline 29. & 4 & pruszkowski & 653 & 76,6 & 538,2 & 614,8 & 246 & 2,2 & 2,5 & - & - & - \\
\hline 30. & 4 & $\begin{array}{l}\text { warszawski } \\
\text { zachodni }\end{array}$ & 212 & 140,5 & 453,4 & 593,9 & 534 & 0,8 & 1,1 & - & + & + \\
\hline 31. & 4 & wołomiński & 246 & 45,8 & 1021,8 & 1067,6 & 954 & 1,07 & 1,12 & - & - & + \\
\hline 32. & 4 & żyrardowski & 143 & 105,8 & 446,0 & 551,8 & 533 & 0,8 & 1,0 & + & - & - \\
\hline 33. & 5 & ciechanowski & 85 & 112,9 & 812,1 & 925,0 & 1060 & 0,8 & 0,9 & - & - & - \\
\hline 34. & 5 & ostrołęcki & 42 & 342,8 & 1134,2 & 1477,0 & 2095 & 0,5 & 0,7 & - & - & - \\
\hline 35. & 5 & płocki & 62 & 395 & 879,9 & 1274,9 & 1796 & 0,5 & 0,7 & + & - & + \\
\hline 36. & 5 & radomski & 99 & 314,7 & 1001,8 & 1316,5 & 1530 & 0,7 & 0,9 & + & - & - \\
\hline 37. & 5 & siedlecki & 51 & 177,4 & 909,2 & 1086,6 & 1603 & 0,6 & 0,7 & - & - & - \\
\hline
\end{tabular}

Źródło: opracowanie własne na podstawie danych z BDL

W drugiej grupie średnia wielkość gęstości zaludnienia wynosi 63 osoby na $1 \mathrm{~km}^{2}$. Największy przyrost dróg nastąpił w powiecie płońskim - 204,2 km. Na drugim miejscu znajduje się powiat zwoleński, który jak widać, zwiększył udział liczby kilometrów drogi względem powierzchni terenu o $0,3 \mathrm{~km} / \mathrm{km}^{2}$. Najmniejszym przyrostem dróg wyróżnia się powiat pułtuski, który ze względu na tę wielkość mógłby znajdować się w grupie pierwszej, jednak zdecydowano, że nadrzędną zmienną decydującą o przydziale do danej grupy będzie gęstość zaludnienia, toteż powiat ten przydzielono do grupy drugiej. Ciekawymi do dalszej analizy w tej grupie stają się powiat sierpecki i ostrowski, które osiągnęły podobną wielkość przyrostu dróg (odpowiednio 170,7 km i $175 \mathrm{~km}$ ).

W trzeciej grupie, największym przyrostem dróg może pochwalić się powiat garwoliński z wynikiem $246,3 \mathrm{~km}$. Na drugim miejscu jest powiat wyszkowski-192,5 km. W obu przypadkach liczba kilometrów drogi w stosunku do powierzchni terenu zwiększyła się o 0,2 km/km². Najniższy przyrost dróg ma powiat szydłowiecki - 36,5 km. Powiat ten odznacza się najmniejszą powierzchnią terenu z wszystkich powiatów województwa mazowieckiego, z czego 1/3 terenu pokryta jest lasem i obszarem chronionego obszaru [Strzelecki 2013, s. 20].

Czwartą grupę charakteryzuje bliskość położenia względem Warszawy. Średnia gęstość zaludnienia wynosi 267 osób na 1 km². Największym przyrostem dróg z analizowanej grupy odznacza się powiat piaseczyński - 161,8 km. Na drugiej pozycji, względem poziomu 
przyrostu dróg, znajduje się powiat warszawski zachodni - 140,5 km, a na ostatniej - powiat wołomiński - 45,8 km. Należy zaznaczyć, że powiat wołomiński charakteryzuje się już dużą gęstością dróg na swoim terenie, ponad 1000 km, zatem można wnioskować, że wydatki inwestycyjne na drogi mogły być przeznaczone w większym stopniu na ich modernizację. W ostatniej, piątej grupie postanowiono zebrać wszystkie powiaty wokół ośrodków subregionalnych, do których zalicza się powiaty: ciechanowski, radomski, ostrołęcki, płocki i siedlecki. Największy przyrost dróg w danej grupie ma powiat płocki - $395 \mathrm{~km}$. Na drugiej pozycji znajduje się powiat ostrołęcki - ponad $342 \mathrm{~km}$.

Na podstawie tego etapu badania można stwierdzić, iż zapewnienie o porównywalności powiatów i ich podział na „podobne” grupy, nadal nie umożliwia pomiaru efektywności kosztowej z tego względu, że dotychczas przeprowadzona analiza nie ujawniła w jakich kategoriach inwestycje były zrealizowane na terytorium danego powiatu. Zestawienie wydatków inwestycyjnych, gdzie nie są znane kategorie inwestycji, z przyrostem dróg, nie daje możliwości prawidłowego pomiaru efektywności kosztowej.

Jak widać na podstawie dotychczas zaprezentowanych wyników badania, niezwykle trudne byłoby przeprowadzenie pomiaru efektywności kosztowej, gdyż ograniczeniem jest brak szczegółowych informacji na temat projektów inwestycyjnych, które były finansowane z wydatków na inwestycje. W związku z tym skupiono się na odszukaniu w statystykach publicznych szczegółów dotyczących projektów inwestycyjnych na temat budowy dróg lokalnych, aby zbadać, jakie inwestycyjne były wykonane. Z przeprowadzonej analizy można było wnioskować, że najwięcej potrzebnych informacji jest dla projektów inwestycyjnych, które finansowane były ze środków unijnych. Warto więc w tym miejscu przyjrzeć się, w jaki sposób system wsparcia unijnego wpływa na działalność inwestycyjną mającą na celu przemiany w dziedzinie dróg lokalnych. W pierwszej kolejności została przedstawiona informacja o wysokości dofinansowania unijnego na drogi lokalne.

\section{Weryfikacja możliwości stosowania audytu efektywnościowego w obszarze transportu na podstawie danych nt. dofinansowania ze środków strukturalnych Unii Europejskiej}

Jedną z możliwości pokrywania lokalnych wydatków inwestycyjnych są środki struk-

turalne z UE [Wojtowicz-Żygadło, Szczygieł 2012, s. 123]. Wartości dofinansowania ze środków strukturalnych Unii Europejskiej na transport lokalny w powiatach województwa mazowieckiego zostały uzyskane z bazy KSI SIMIK. Z uwagi na konieczność zapewnienia porównywalności pomiędzy powiatami, na potrzeby niniejszego badania, interesujące było zwłaszcza określenie wartości dofinansowania środków unijnych na drogi lokalne dla powiatów ziemskich województwa mazowieckiego. Wartość bezwzględna dofinansowania unijnego na drogi lokalne w latach 2007-2015 w powiatach woj. mazowieckiego została przestawiona na rycinie 3.

Pod względem wartości dofinansowania z UE na drogi lokalne w latach 2007-2015 najwyższą pozycję zajmuje powiat płocki - ponad $56 \mathrm{mln}$ zł. Drugim z kolei jest powiat ostro- 
łęcki z kwotą ponad 46 mln zł. W przypadku powiatu ostrołęckiego udział dofinansowania stanowił wydatki na przebudowę dróg zarówno gminnych, jak i powiatowych. W odniesieniu do powiatu płockiego, znaczący udział środków unijnych został przeznaczony na odbudowę dróg gminnych uszkodzonych w wyniku powodzi z 2010 r. na terenie gminy Słubice.

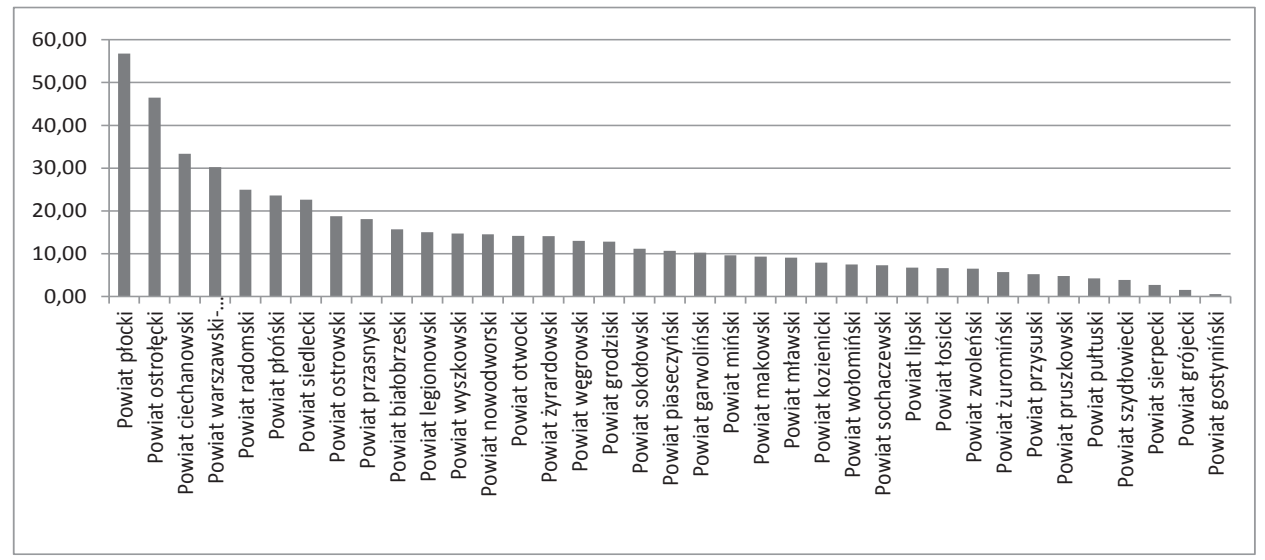

Ryc. 3. Dofinansowanie UE na drogi lokalne w powiatach województwa mazowieckiego w ujęciu bezwzględnym (w mln zł), w latach 2007-2015

Źródło: opracowanie własne na podstawie danych z bazy KSI SIMIK

Kolejnym zadaniem badawczym, podjętym w niniejszym artykule, było przedstawienie zależności pomiędzy dofinansowaniem unijnym na drogi lokalne w powiatach województwa mazowieckiego a przyrostem dróg lokalnych w tych powiatach (ryc. 4). Celem była weryfikacja i próba odpowiedzi na pytanie: czy ta zależność będzie miarodajna dla dokonania porównań efektywności kosztowej?

Największym przyrostem długości dróg mógł pochwalić się powiat płocki, gdzie przy wysokim poziomie dofinansowania przyrost dróg osiaga na poziomie średnio $395 \mathrm{~km}$. Na drugim miejscu znalazł się powiat ostrołęcki, który miał wynik o 53 km mniejszy. W grupie II (wysokie dofinansowaniu przy niskim poziomie przyrostu dróg) znajdują się powiaty garwoliński, makowski, płoński i radomski. Powiat ciechanowski, wraz z powiatem warszawskim zachodnim pojawił się w grupie IV, co oznacza że wysoki poziom dofinansowania z UE nie przekłada się na wysoki poziom przyrostu dróg $(204 \mathrm{~km})$. Czy zatem można powiedzieć, że powiaty te wykorzystują środki unijne nieefektywnie, czy też może w powiatach tych były realizowane dodatkowe elementy infrastruktury, np. drogi rowerowe czy dodatkowe oświetlenie? Z uwagi na fakt, iż nie można tego stwierdzić, podjęto się próby wejścia na większy poziom szczegółowości i przeanalizowanie projektów inwestycyjnych dofinansowanych ze środków unijnych w poszczególnych grupach „podobnych” do siebie powiatów.

(Na wykresie zostały oznaczone powiaty, które rozpatrywano w dalszej analizie) 


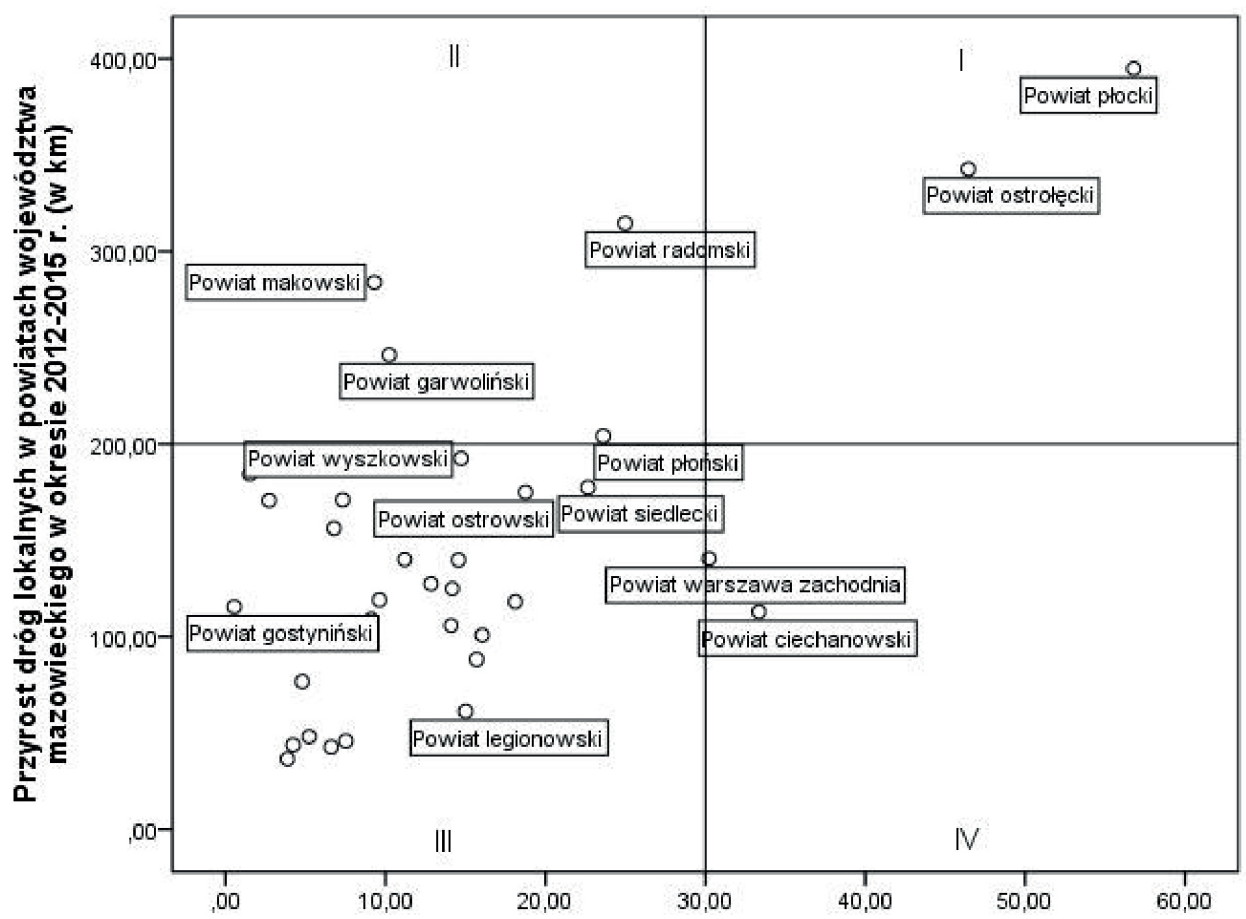

Dofinansowanie z UE na drogi lokalne w ujęciu bezwzględnym (w mln zl)

Ryc. 4. Zależność pomiędzy dofinansowaniem unijnym na drogi lokalne w ujęciu bezwzględnym

(w mln zł) i przyrostem dróg lokalnych w powiatach województwa mazowieckiego (w km), w latach 2012-2015

Źródło: opracowanie własne na podstawie bazy danych BDL

\section{Zależność pomiędzy dofinansowaniem z UE na drogi lokalne a przyrostem przebudowa- nych dróg lokalnych w wybranych powiatach województwa mazowieckiego w latach 2007-2015}

Na tym etapie wykorzystano podział powiatów na 5 uprzednio zdefiniowanych grup (tabela 1), z których do dalszej, szczegółowej analizy, wybrano tylko grupę 1. Wybór był motywowany tym, iż w powiatach z grupy 1. były realizowane projekty, na temat których można było uzyskać najwięcej informacji o dodatkowych elementach wybudowanej infrastruktury. Pozostałe grupy charakteryzowały się nieco niższą liczbą informacji na temat przeprowadzanych projektów inwestycyjnych.

W początkowej fazie tego etapu analizy, przedstawiono zależność pomiędzy dofinansowaniem unijnym na drogi lokalne a przyrostem dróg lokalnych w powiatach należących do grupy 1. Chociaż w drugim etapie badania stwierdzono, że zależność ta jest niewystarczająca do przeprowadzenia pomiaru efektywności kosztowej, postanowiono przedstawić tę 
zależność w celu zidentyfikowania podgrup z danej grupy, które charakteryzowały się „podobnymi" wartościami. Interesującymi podgrupami do dalszej analizy stają się: (1) powiaty lipski i makowski, które charakteryzują się „podobną" wartością dofinansowania unijnego na drogi lokalne przy znacznie różnym poziomie przyrostu dróg (ryc. 5) oraz (2) powiat żuromiński i powiat węgrowski, które charakteryzują się „podobną” wielkością przyrostu dróg lokalnych, ale znacznie różnym poziomem dofinansowania unijnego. W dalszej analizie skupiono się na zidentyfikowaniu poszczególnych kategorii inwestycji projektów realizowanych na terytorium powiatów należących do grupy 1, w celu stwierdzenia, czym spowodowane były różnice w przyroście dróg lokalnych (powiat lipski i makowski) i w poziomie dofinansowania unijnego (powiat żuromiński i powiat węgrowski).

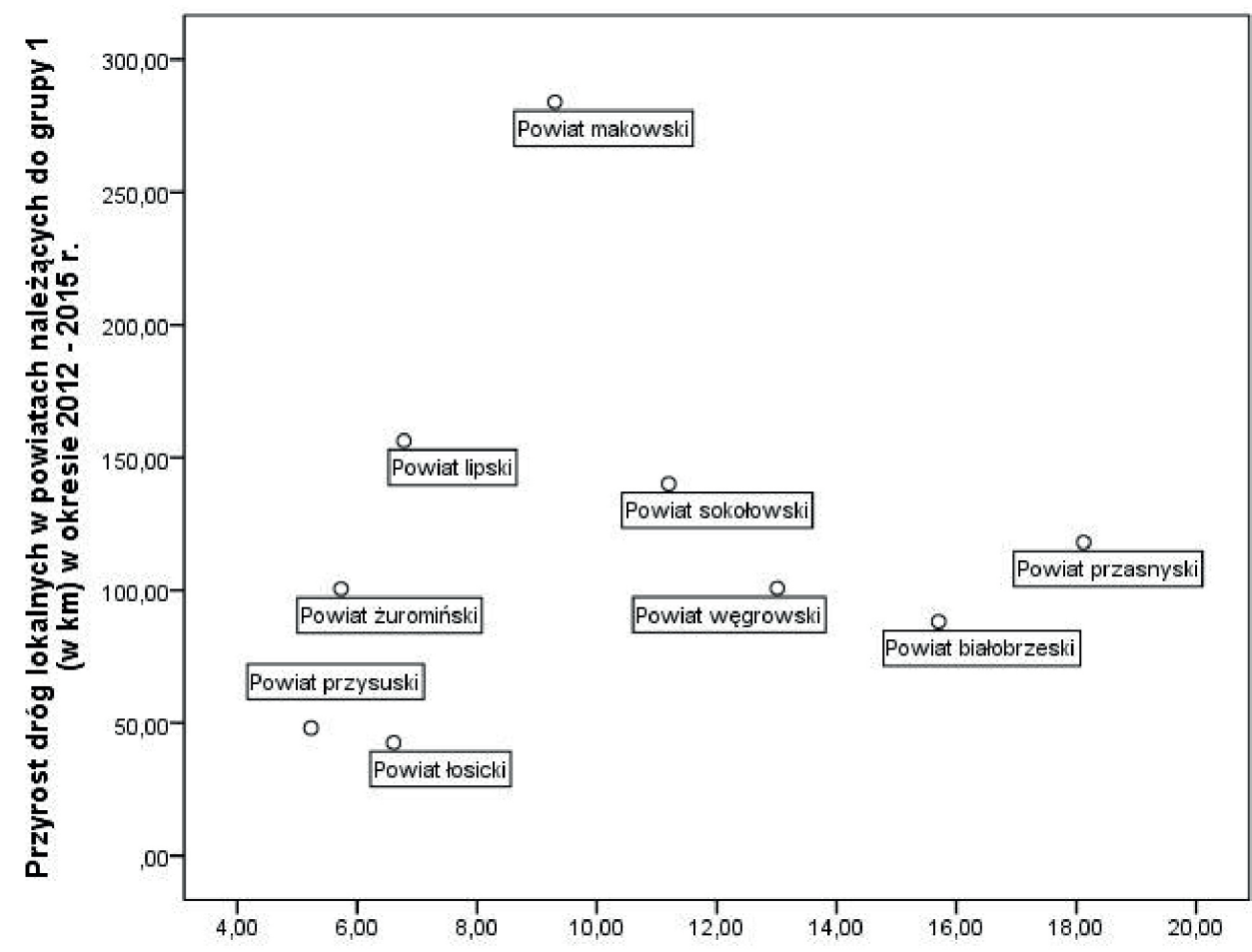

Dofinansowanie $z$ UE na drogi lokalne w ujęciu bezwględnym (w $\mathrm{mln} z \mathrm{l}$ )

Ryc. 5. Zależność pomiędzy dofinansowaniem unijnym na drogi lokalne w ujęciu bezwzględnym (w mln zł) i przyrostem dróg lokalnych w powiatach należących do 1. grupy

Źródło: opracowanie własne na podstawie danych SIMIK i BDL

\section{Porównanie wartości inwestycji drogowych w powiatach lipskim i makowskim}

Z ryciny 5 można odczytać, że przy niewielkiej różnicy w wielkości dofinansowania powiat lipski 6,7 mln zł, powiat makowski 9,3 mln zł - wielkość przyrostu dróg jest różna. 
Tabela 2 zawiera szczegółowe informacje na temat dodatkowych elementów infrastruktury wykonywanych w ramach projektu. Sporządzenie tej tabeli jest ważnym elementem analizy, dzięki któremu można stwierdzić, jakie kategorie inwestycji zostały realizowane w projektach inwestycyjnych na drogi lokalne. Dodatkowo, można również odczytać, jaka była faktyczna wielkość przebudowy bądź budowy drogi.

Tabela 2. Szczegółowe informacje na temat realizowanych projektów drogowych finansowanych z UE w powiecie lipskim, makowskim, węgrowskim i żuromińskim

\begin{tabular}{|c|c|c|c|c|c|c|c|c|c|c|c|c|c|}
\hline 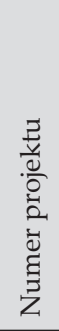 & $\begin{array}{l}\overrightarrow{0} \\
\cdot \overrightarrow{0} \\
\overrightarrow{3} \\
0 \\
0\end{array}$ & 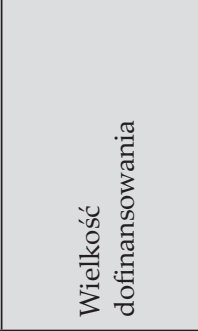 & 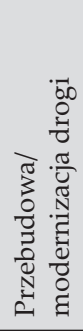 & 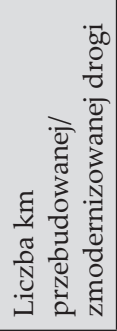 & 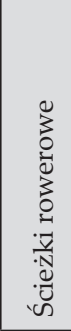 & 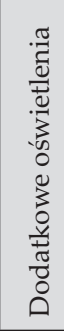 & $\begin{array}{l}\bar{v} \\
\bar{z} \\
0 \\
0 \\
\text { U }\end{array}$ & 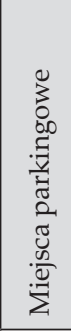 & 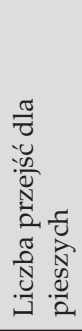 & 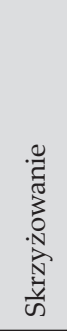 & $\begin{array}{l}\overrightarrow{0} \\
\text { N } \\
\text { N }\end{array}$ & 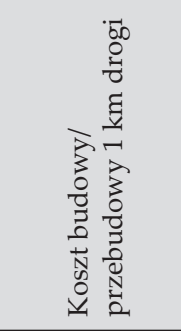 & 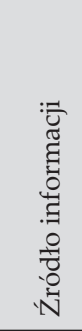 \\
\hline 1. & \multirow{4}{*}{$\begin{array}{l}\frac{\bar{v}}{w} \\
:=\end{array}$} & 469163,46 zł & + & 2,29 & - & - & - & - & - & - & - & 204 874,87 zł & SIWZ \\
\hline 2. & & $1856933,54 \mathrm{zł}$ & + & 12,18 & b.d. & b.d. & + & b.d. & b.d. & b.d. & b.d. & $152457,60 \mathrm{zł}$ & WZI \\
\hline 3. & & $2762276,66 \mathrm{zt}$ & + & 7,39 & b.d. & b.d. & + & b.d. & b.d. & b.d. & b.d. & 373 785,75 zł & WZI \\
\hline 4. & & 1696 130,20 zł & + & 3,70 & b.d. & b.d. & + & b.d. & b.d. & b.d. & b.d. & 458 413,57 zł & WZI \\
\hline 5. & \multirow{3}{*}{ 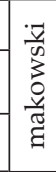 } & 1302 261,86 zł & + & 3,74 & b.d. & b.d. & + & b.d. & b.d. & b.d. & b.d. & 348 198,36 zł & WZI \\
\hline 6. & & $6009481,90 \mathrm{zł}$ & + & 14,10 & - & - & + & - & - & + & + & $426204,39 \mathrm{zt}$ & SIWZ \\
\hline 7. & & 1992344,62 zł & + & 2,25 & - & - & + & - & - & - & + & $885486,50 \mathrm{zł}$ & SIWZ \\
\hline 8. & \multirow{4}{*}{ 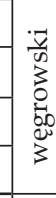 } & $1139398,37 \mathrm{zf}$ & \multirow{2}{*}{+} & \multirow{2}{*}{9,07} & \multirow{2}{*}{ b.d. } & \multirow{2}{*}{ b.d. } & \multirow{2}{*}{ b.d } & \multirow{2}{*}{+} & \multirow{2}{*}{ b.d. } & \multirow{2}{*}{+} & \multirow{2}{*}{+} & \multirow{2}{*}{$251245,51 \mathrm{zł}$} & \multirow{2}{*}{ BIP } \\
\hline 9. & & $1139398,37 \mathrm{zł}$ & & & & & & & & & & & \\
\hline 10. & & $8328357,98 \mathrm{zł}$ & + & 10,55 & b.d. & b.d. & b.d. & b.d. & b.d. & + & + & 789417,82 zł & WZI \\
\hline 11. & & $2406126,00 \mathrm{zł}$ & + & 0,40 & b.d. & b.d. & + & + & b.d. & & + & $6015315,00 \mathrm{zt}$ & WZI \\
\hline 12. & \multirow{3}{*}{ 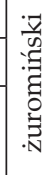 } & $1217006,91 \mathrm{zł}$ & \multirow{2}{*}{$\begin{array}{llll}+ & & l & \end{array}$} & \multirow{2}{*}{7,51} & \multirow{2}{*}{ b.d. } & \multirow{2}{*}{ b.d. } & \multirow{2}{*}{+} & \multirow{2}{*}{ b.d. } & \multirow{2}{*}{ b.d. } & \multirow{2}{*}{ b.d. } & \multirow{2}{*}{ b.d. } & \multirow{2}{*}{324 103,04 zł } & \multirow{2}{*}{ WZI } \\
\hline 13. & & $1217006,91 \mathrm{zł}$ & & & & & & & & & & & \\
\hline 14. & & 3293314,66 zł & + & 7,07 & b.d. & b.d. & + & b.d. & b.d. & b.d. & b.d. & 465815,37 zł & WZI \\
\hline
\end{tabular}

Legenda:

"+ " oznacza, że element infrastruktury został zrealizowany w projekcie

"-" oznacza, że element infrastruktury nie był realizowany w projekcie

"b.d." oznacza brak informacji o istnieniu danego elementu w projekcie

SIWZ - Specyfikacja istotnych warunków zamówienia

WZI - Wolne zasoby internetowe

BIP - Biuletyn Informacji Publicznej

Źródło: opracowanie własne na podstawie bazy SIMIK, SIWZ i wolnych zasobów internetowych 
W tabeli 2 Numer projektu jest odpowiedni do Nazwy projektu, jaki został zrealizowany $\mathrm{w}$ danym powiecie (tabela 5, załącznik 1). Zgodnie z tą informacja, wszystkie projekty, zarówno te prowadzone w powiecie legionowskim, jak i makowskim, były związane z przebudową już istniejącej drogi, dlatego w kolumnie o nazwie Przebudowa/modernizacja drogi postawiono znak ,"+". Z Nazwy projektu, w niektórych projektach, można odczytać informację na temat długości przebudowanej lub wybudowanej drogi.

Przy rozważaniach nad inwestycjami realizowanymi przez powiat lipski, z tabeli można odczytać, że w opracowaniu były cztery projekty. W przypadku trzech projektów widnieje informacja o liczbie kilometrów przebudowanej drogi, natomiast projekt o numerze 1, pt.: Przebudowa-modernizacja drogi gminnej Gardzienice Kolonia - Stare Gardzienice - Ciepielów, nie uwzględniał tej wielkości. Szczegółowe informacje na temat projektu pozyskano z Biuletynu Informacji Publicznej Gminy Ciepielów. Z dokumentu Specyfikacja istotnych warunków zamówienia, można odczytać informację na temat długości przebudowanej drogi. Przedmiotem zamówienia jest przebudowa drogi gminnej, która obejmuje dodatkowo opis technicznych elementów wspomnianej przebudowy. Dostępny opis projektu nie uwzględnia dodatkowej infrastruktury, toteż w powyższej tabeli, w każdej rubryce wstawiono znak „--".

Kolejny projekt realizowany w powiecie lipskim otrzymał dofinansowanie w kwocie ponad 1,8 mln zł. W ramach tego projektu przebudowano ponad $12 \mathrm{~km}$ drogi ${ }^{3}$. Niestety, w tym przypadku nie odnaleziono dokumentu SIWZ. Szczegółowe informacje pobrano z wolnych zasobów internetowych. W ramach tego projektu, oprócz przebudowy drogi, wybudowano chodnik - $12 \mathrm{~m}^{2}{ }^{4} \mathrm{~W}$ związku z powyższym, wstawiono znak ",+" w kolumnie o nazwie Chodnik. W ramach kolejnych dwóch projektów - 3 i 4, również wybudowano chodniki o długości odpowiednio - $875 \mathrm{~m}^{2}$ i $210 \mathrm{~m}^{2}$.

Powiat makowski w porównaniu z powiatem lipskim realizował trzy projekty. Największe dofinansowanie otrzymał projekt o nazwie Przebudowa drogi powiatowej nr 3238W Przasnysz - Leszno - Karniewo - Przemiarowo od km 16+051 do km 30+150 wraz z infrastruktura towarzyszaca. W nazwie projektu widnieje informacja o liczbie kilometrów przebudowanej drogi. Pozostałe informacje pozyskano z dokumentu SIWZ, który pobrano z Biuletynu Informacji Publicznej Starostwa Powiatowego w Makowie Mazowieckim. Oprócz informacji technicznych opisujących przebudowę drogi, pozyskano dane, iż w ramach tej inwestycji wykonano budowę dwóch skrzyżowań typu rondo w miejscowości Karniewo oraz budowę chodników i zjazdów na odcinku przebiegającym przez tereny zabudowane w wielkości 6048 mb. Wobec tego, w tabeli 2 oznaczono znakiem ",+ elementy infrastruktury, które zostały realizowane.

W odniesieniu do projektu nr 5 pod tytułem: Modernizacja dróg w Gminie Sypniewo - Etap III Realizacja części etapu w technologii masy asfaltowej, poszczególne informacje pozyskano z wolnych zasobów internetowych. Na oficjalnej witrynie gminy Sypniewo widnieje informacja, że powyższy projekt był realizowany z RPO WM z kwotą dofinansowania na pozio-

\footnotetext{
${ }^{3}$ Informacja ta została pozyskana z opisu Nazwy projektu.

${ }^{4}$ http://www.rynekzdrowia.pl/oferty/przetargi/2009115496.html, [dostęp 01.02.2018].
} 
mie 85\%. Z opisu można jedynie odczytać, że „Zakończyła się realizacja projektu w ramach RPO WM dla przebudowy dróg gminnych w miejscowościach: Nowy Szczeglin - Szczeglin Poduchowny, Biedrzyce Koziegłowy - 3 odcinki drogowe, Zamość, Sypniewo ul. Wspólna, Sypniewo ul. Dzieci Polskich." Dodatkowe informacje, na temat długości przebudowanych dróg i elementów infrastruktury pozyskano z wolnych zasobów internetowych, gdyż nie można odnaleźć SIWZ sporządzonego do powyższego zamówienia ${ }^{5}$. Tabelę uzupełniono o wartość kilometrów przebudowanej drogi i wstawiono znak ", ${ }^{\text {” }}$ w kolumnie Chodnik w ramach tej inwestycji położono nowy chodnik o długości $169 \mathrm{mb}$. Puste kolumny w tym przypadku oznaczają brak informacji o dodatkowych elementach infrastruktury. Nie można jednak wstawić znaku „,-", gdyż nie ma pewności, że dany element infrastruktury w tej inwestycji nie wystąpił. Pozyskanie dokładnych informacji jest możliwe w przypadku istnienia SIWZ, czy nawet ogłoszenia o przetargu, które niestety szybko znikają ze stron gmin lub powiatów.

Ostatni projekt w tym powiecie, pt: Przebudowa drogi gminnej nr 210222 Wna odcinku o dtugości 2,245 km - ulica Mazowiecka, Przemysłowa i Szkolna, związany był z przebudową drogi o długości 2,245 km. W przypadku tej inwestycji pozyskano dodatkowe informacje z dokumentu SIWZ, znajdującego się na oficjalnej witrynie gminy Karniewo ${ }^{6}$. Zakres inwestycji obejmuje dodatkowo budowę chodników (nie jest podana wielkość wybudowanego chodnika) oraz budowę zjazdów na przyległe działki. W pozostałe miejsca w tabeli wstawiono znak ,,$-"$

\section{Porównanie wartości inwestycji drogowych w powiatach żuromińskim i wegrowskim}

Jak zobrazowano na rycinie 6, wartości przyrostu dróg w powiatach żuromińskim i węgrowskim są podobne, zaś różnic można dopatrzeć się w wielkości dofinansowania. W przypadku powiatu węgrowskiego można zauważyć, że realizował cztery projekty, z czego numery 8 i 9 dotyczyły tej samej inwestycji. Łączne dofinansowanie wyniosło ponad 2,2 mln zł. W ramach tej inwestycji przebudowano 6,35 km drogi na terenie gminy Stoczek i 2,72 km drogi w gminie Sadowne. Łączna długość przebudowanych dróg wynosi 9,07 km. Dodatkowe informacje zostały pobrane z Biuletynu Informacji Publicznej Starostwa Powiatowego w Węgrowie. Zgodnie z powyższym, inwestycja obejmowała obustronną przebudowę chodnika (brak informacji o długości przebudowanego chodnika), przebudowę 115 zjazdów publicznych i indywidualnych oraz przebudowę 10 skrzyżowań.

\footnotetext{
${ }^{5}$ http://www.przetargi.egospodarka.pl/88640_Modernizacja-drog-w-gminie-Sypniewo-etapIII-Realizacja-czesci-etapu-w-technologii-masy-asfaltowej-1-Przebudowa-drogi-gminnej-NowySzczeglin-Szczeglin-Poduchowny-2-Przebudowa-drogi-gminnej-w-msc-Biedrzyc_2010_2.html, [dostęp 02.02.2018].

${ }^{6} \mathrm{http}: / /$ www.biuletyn.net/ntbin/start.asp?podmiot=karniewo/\&strona=13\&typ=menu\&menu=35\&id=2 45\&str=1 , [dostęp 02.02.2018].
} 


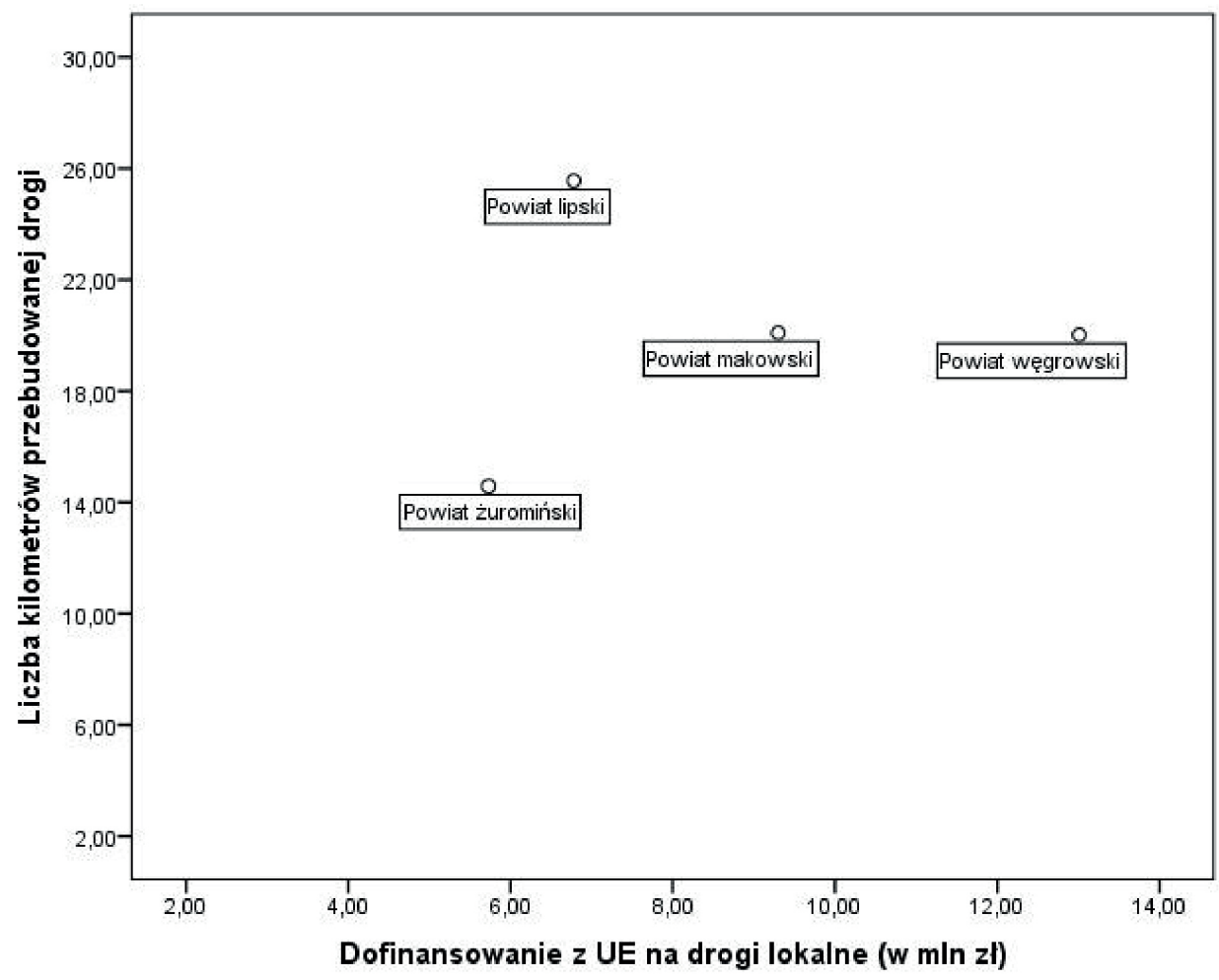

Ryc. 6. Zależność pomiędzy dofinansowaniem unijnym na drogi lokalne w ujęciu bezwzględnym (w mln zł) i liczbą kilometrów przebudowanej drogi lokalnej w powiatach należących do 1. grupy

Źródło: opracowanie własne na podstawie bazy SIMIK, SIWZ i wolnych zasobów internetowych

Ze wszystkich analizowanych projektów największe dofinansowanie otrzymał powiat węgrowski na wykonanie projektu nr 10 o nazwie Przebudowa drogi gminnej Gwizdały - Łazy - Brzuza, Gmina Łochów. Wartość tego dofinansowania opiewała na sumę ponad $8 \mathrm{mln}$ zł. W ramach tej inwestycji przebudowano ponad $10 \mathrm{~km}$ drogi, koszt jednostkowy przebudowanej drogi wyniósł 785 694,15 zł. Dodatkowo, inwestycja ta obejmowała przebudowę dwóch skrzyżowań i zjazdów do posesji ${ }^{7,8}$. Ostatni projekt realizowany w powiecie węrowskim opiewał na sumę ponad $2 \mathrm{mln}$ zł. W ramach tej inwestycji przebudowano 0,41 km drogi ${ }^{9}$. Dodatkowo, zakres rzeczowy obejmował wykonanie: chodników z kostki brukowej, miejsc parkingowych i zjazdów z kostki brukowej.

\footnotetext{
${ }^{7}$ http://www.kurier-w.pl/uroczyste-otwarcie-drogi-gminnej-w-gwizdalach-29-05-2012/, [dostęp 02-02-18].

${ }^{8}$ https://mojepanstwo.pl/dane/zamowienia_publiczne/1769996,przebudowa-drogi-gminnej-gwizdalylazy-brzuza-w-gminie-lochow, [dostęp 02.02.2018].

${ }^{9}$ http://www.gminalochow.pl/content/wykonana_droga_przebiega_przez_budziska_kaliska_gwizdaly-178, [dostęp 02.02.2018].
} 
Powiat żuromiński realizował 3 projekty, z czego dwa były wiązane z tą samą inwestycją. Łączna długość przebudowanej drogi wynosi ponad 7,5 $\mathrm{km}^{10}$. W ramach tego projektu wybudowano 1,2 km chodnika. Ostatni projekt prowadzony w powiecie żuromińskim otrzymał dofinansowanie w wysokości 3293 314,66 zł. Inwestycja ta obejmowała przebudowę ponad 7 km drogi oraz przebudowę skrzyżowania i przebudowę chodników.

Kolejnym krokiem, w realizacji celu pracy, było stworzenie wykresu odzwierciedlającego faktyczną zależność pomiędzy wielkością dofinansowania w poszczególnych badanych powiatach a liczbą kilometrów przebudowanej drogi. W związku z powyższym zsumowano wartość dofinansowania dla danego powiatu, jak również zsumowano wartość liczby przebudowanych kilometrów dróg.

W tym przypadku porównywalność powiatów mogłaby wyglądać nieco inaczej niż na rycinie 5 . Z wykresu można odczytać, że powiat makowski i powiat węgrowski przebudowały podobną liczbę dróg lokalnych. Łączna liczba kilometrów przebudowanej drogi w powiecie makowskim wynosiła 20,9 km, natomiast w powiecie węgrowskim 20,2 km. Jednak wielkość dofinansowania różni się o przeszło $3 \mathrm{mln}$ zł. Jak zatem wygląda koszt jednostkowy przebudowania drogi w powiecie węgrowskim i makowskim? Na kolejnej rycinie przestawiono zależność pomiędzy liczbą kilometrów przebudowanej drogi a kosztem jednostkowym przebudowy $1 \mathrm{~km}$ drogi (ryc. 7).

Najwyższy koszt jednostkowy przebudowy 1 kilometra drogi występuje w powiecie węgrowskim. Interesujące, do dalszej analizy, stają się w tym momencie powiaty węgrowski i makowski, w których przebudowano prawie identyczną długość drogi, jednak koszt jednostkowy w powiecie węgrowskim jest wyższy o przeszło 186 tysięcy zł. Należy tym samym zadać pytanie, jakie czynniki wpłynęły na to, że powiat węgrowski był „droższy” od powiatu makowskiego?

Kolejnym etapem badania była szacunkowa wycena poszczególnych inwestycji realizowanych w obu powiatach. Pomocna w osiągnięciu tego celu jest tabela z szacunkowym kosztem wybudowania infrastruktury dodatkowej (tabela 3).

\footnotetext{
${ }^{10}$ https://www.zuromin-powiat.pl/droga-lutocin-zimolza/2011-, [dostęp 03.02.2018].
} 


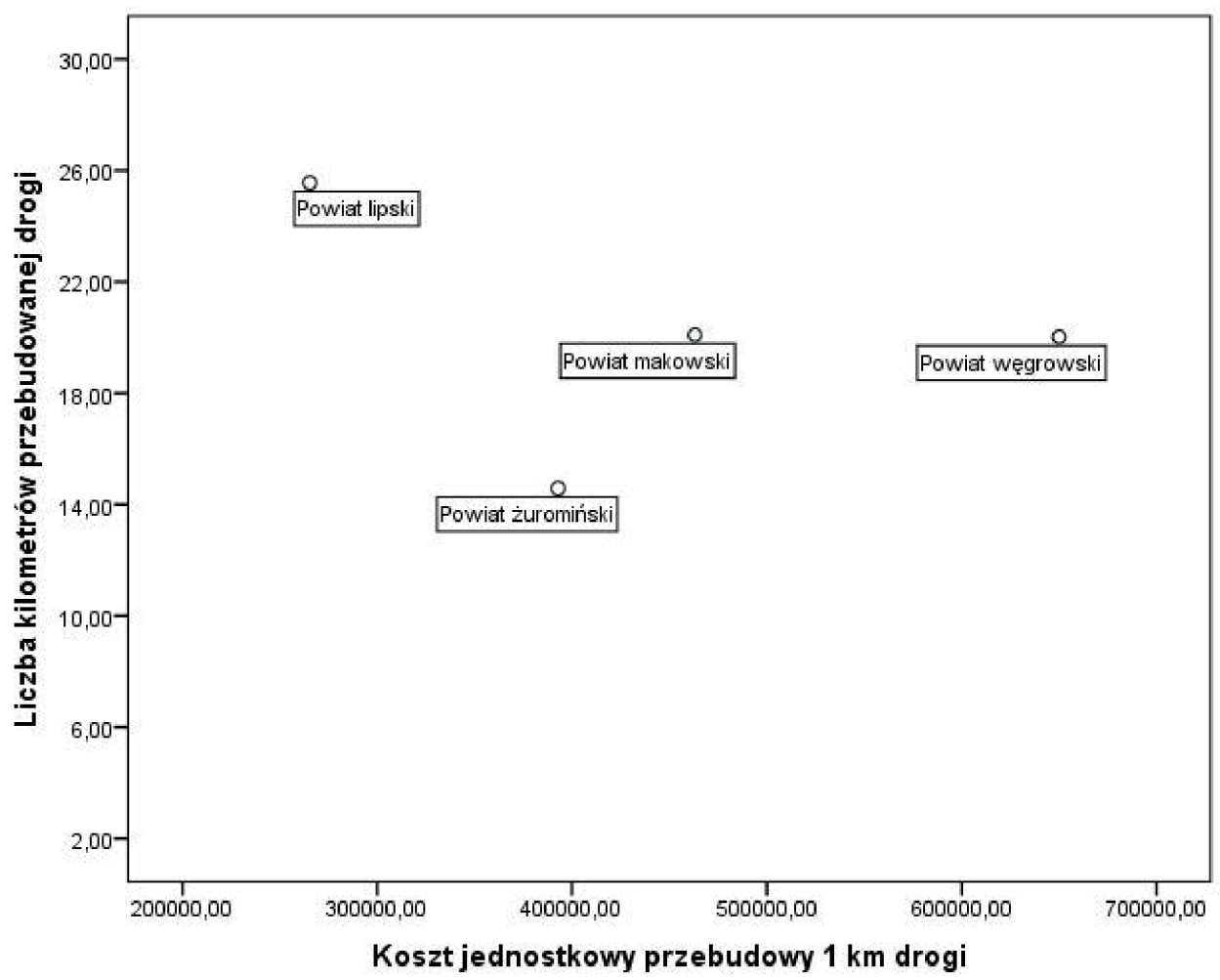

Ryc. 7. Zależność pomiędzy kosztem jednostkowym przebudowanej drogi w ujęciu bezwzględnym a liczbą kilometrów przebudowanej drogi lokalnej w powiatach należących do 1. grupy

Źródło: opracowanie własne na podstawie bazy SIMIK, SIWZ i wolnych zasobów internetowych

Tabela 3. Szacunkowe koszty wybudowania infrastruktury dodatkowej

\begin{tabular}{|l|r|}
\hline Dodatkowa infrastruktura & Szacunkowa cena \\
\hline Ścieżka rowerowa & $300 \mathrm{zł} / \mathrm{mb}$ \\
\hline Chodnik & $200 \mathrm{zł} / \mathrm{mb}$ \\
\hline Skrzyżowanie (budowa ronda) & $3000000 \mathrm{zł}-5000000 \mathrm{zł}$ \\
\hline Skrzyżowanie (przebudowa) & $500000 \mathrm{zł}-1500000 \mathrm{zł}$ \\
\hline Miejsca parkingowe (1 miejsce parkingowe) & $1500 \mathrm{zł}$ \\
\hline Zjazdy (1 zjazd ) & $400 \mathrm{zł}-700 \mathrm{zł}$ \\
\hline Przejścia dla pieszych & $6000-8000 \mathrm{zł}$ \\
\hline
\end{tabular}

Źródło:

1) https://budzet.um.poznan.pl/pbo2017/przykladowe-koszty_/,

2) https://obywatelski.sosnowiec.pl/projekty/14/2/przykladowe_koszta.html,

3) http://www.pomorska.pl/motofakty/na-drogach/a/czekamy-na-to-skrzyzowanie-koszt-przebudowywyniesie-15-mln-zl,11833392/, [dostęp: 29.01.2018] 
Autorzy artykułu mają świadomość, że źródła, z których pobrano szacunkowe ceny związane są z budową infrastruktury $\mathrm{w}$ wielkich miastach, stanowią jedne z nielicznych informacji, które można pobrać z ogólnie dostępnych, bezpłatnych zasobów internetowych. Przyjęto założenie, iż mniejsze gminy mogą nie mieć dostępu do niektórych źródeł płatnych lub nawet nie mają informacji o ich istnieniu. Z obserwacji empirycznej wynika również, iż jednostki samorządu terytorialnego niejednokrotnie posługują się wynikami przetargów z innych, podobnych inwestycji. Postanowiono przeprowadzić symulację wyceny poszczególnych inwestycji w powiatach na podstawie ogólnie dostępnych zasobów internetowych. W tabeli 4 zebrano wycenę poszczególnych elementów infrastruktury.

Tabela 4. Szacunkowa wycena elementów infrastruktury drogowej w projektach realizowanych w powiecie makowskim i węgrowskim

\begin{tabular}{|c|c|c|c|c|c|}
\hline Lp. & Powiat makowski & $\begin{array}{l}\text { Jednostka } \\
\text { miary }\end{array}$ & Wartość & $\begin{array}{l}\text { Koszt } \\
\text { jedn. }\end{array}$ & Koszt w zł \\
\hline 1. & \multicolumn{5}{|l|}{$\begin{array}{l}\text { Wielkość dofinansowania } \\
\text { (w zaokrągleniu) }\end{array}$} \\
\hline \multicolumn{6}{|c|}{ Poszczególne elementy infrastruktury: } \\
\hline 2. & Chodniki & $\mathrm{mb}$ & 6217 & 300 & 1865100 \\
\hline 3. & Chodniki pozostałe & $\mathrm{mb}$ & b.d. & b.d. & $\mathrm{x}$ \\
\hline 4. & Zjazdy & szt. & b.d. & b.d. & $\mathrm{y}$ \\
\hline 5. & Skrzyżowanie (budowa) & szt. & 2 & 3000000 & 6000000 \\
\hline 6. & SUMA $(2,3,4,5)$ & & & & $7865100+x+y$ \\
\hline \multicolumn{5}{|c|}{ Różnica $(1-6)$} & $1134900-x-y$ \\
\hline Lp. & Powiat węgrowski & $\begin{array}{l}\text { Jednostka } \\
\text { miary }\end{array}$ & Wartość & $\begin{array}{l}\text { Koszt } \\
\text { jedn. }\end{array}$ & Koszt w zł \\
\hline 1. & \multicolumn{5}{|l|}{$\begin{array}{l}\text { Wielkość dofinansowania } \\
\text { (w zaokrągleniu) }\end{array}$} \\
\hline \multicolumn{6}{|c|}{ Poszczególne elementy infrastruktury: } \\
\hline 2. & Chodniki & $\mathrm{mb}$ & b.d. & b.d. & $\mathrm{x}$ \\
\hline 3. & Zjazdy & $\mathrm{mb}$ & b.d. & b.d. & $\mathrm{y}$ \\
\hline 4. & Miejsca parkingowe & szt. & b.d. & b.d. & $\mathrm{z}$ \\
\hline 5. & $\begin{array}{l}\text { Skrzyżowanie } \\
\text { (przebudowa) }\end{array}$ & szt. & 12 & 500000 & 6000000 \\
\hline 6. & Zjazdy & szt. & 115 & 550 & 63250 \\
\hline 7. & SUMA $(2,3,4,5,6)$ & & & & $6063250+x+y+z$ \\
\hline \multicolumn{5}{|c|}{ Różnica (1-7) } & $6936750-x-y-z$ \\
\hline
\end{tabular}

Źródło: opracowanie własne na postawie tabel 2 i 3 
Powiat makowski realizował 3 projekty. W pierwszym z nich była mowa, że w ramach inwestycji wybudowano dwa skrzyżowania typu rondo oraz chodniki o łącznej długości 6048 mb. Drugi z kolei projekt w swoim zakresie miał wybudowanie nowego chodnika o długości 169 mb. Łączna suma zbudowanych chodników wyniosła $6217 \mathrm{mb}$. Natomiast trzeci projekt obejmował budowę chodnika oraz budowę zjazdów, lecz w obu przypadkach nie podano rzędu wielkości wybudowanych elementów. W tabeli 4 oznaczono nieznane wartości kosztów znakami x i y.

Podobna sytuacja była w powiecie węgrowskim. Realizował on również 3 projekty. Zgodnie z informacjami umieszczonymi powyżej, w pierwszym projekcie prowadzonym w powiecie węgrowskim inwestycja obejmowała obustronną przebudowę chodnika, lecz nie uwzględniono rzędu wielkości tej przebudowy. Projekt zawierał również przebudowę 115 zjazdów oraz przebudowę 10 skrzyżowań. Drugi projekt obejmował przebudowę 2 skrzyżowań i przebudowę zjazdów do posesji. Trzeci wykonywał dodatkowo budowę chodników, miejsc parkingowych i zjazdów. Ze wszystkich inwestycji można jedynie wnioskować, że przebudowano łącznie 12 skrzyżowań i 115 zjazdów. Można zatem przypuszczać, że przebudowanie aż 12 skrzyżowań mogło wpłynąć na tak wysoki koszt jednostkowy w powiecie węgrowskim.

Porównując koszty w obydwu powiatach, można zauważyć, że jeżeli koszt przebudowania skrzyżowania wynosi średnio $0,5 \mathrm{mln}$ zł to przebudowanie 12 skrzyżowań daje łączną sumę 6 mln zł. Oznacza to, że koszt budowy dwóch skrzyżowań typu rondo w powiecie makowskim jest podobnie kosztochłonny jak przebudowanie 12 skrzyżowań w powiecie węgrowskim. Zatem można przypuszczać, że wyższy koszt jednostkowy w powiecie węgrowskim nie jest wytłumaczony przez przebudowę 12 skrzyżowań.

Z tabeli 4 wynika, że nieznanymi wielkościami w powiecie makowskim są chodniki (x) i zjazdy (y). Te same nieznane zmienne występują w powiecie węgrowskim. Dodatkową zmienna która różnicuje oba powiaty jest zmienna (z) występująca w powiecie węgrowskim.

Można zatem przypuszczać, że większy koszt jednostkowy w powiecie węgrowskim jest spowodowany kosztem budowy nieznanej liczby miejsc parkingowych (z), których budowy nie zrealizowano w powiecie makowskim.

Z powyższych rozważań wynika, iż brakuje pełnej i porównywalnej informacji, umożliwiającej dokonanie chociażby wstępnej oceny i porównań w zakresie efektywności kosztowej realizowanych inwestycji drogowych na terenie badanych powiatów.

\section{Podsumowanie}

Przeprowadzenie nawet wstępnego audytu efektywnościowego w zakresie pomiaru efektywności kosztowej w dziedzinie wydatków inwestycyjnych na drogi lokalne przez samorządy lokalne na podstawie dostępnych danych statystycznych jest procesem bardzo złożonym. Podczas prowadzenia badań Autorzy „wcielili się w postać wójta lub starosty” (lub mieszkańca danej gminy), który w danym momencie chce sięgnąć do podstawowych źródeł danych w statystyce publicznej, czy innych ogólnie dostępnych źródeł, bez konieczności występowania o takie dane, aby upewnić się, czy inwestycja, która została przeprowa- 
dzona na terenie jego gminy/powiatu w porównaniu z innymi, "podobnymi” jednostkami była „droga” czy „tania”. Niejednokrotnie podejmowanie decyzji musi następować w przyspieszonym tempie i dostęp do tego typu informacji byłby zapewne pomocny dla włodarzy samorządowych czy komisji przetargowych. Celem badania było ustalenie, czy na podstawie danych dostępnych w statystyce publicznej i innych ogólnie dostępnych danych jest możliwe przeprowadzenie wstępnego audytu efektywnościowego w zakresie efektywności kosztowej, a ściślej, czy jest możliwe znalezienie wielkości nakładów i wyników w obszarze infrastruktury drogowej dla wybranych samorządów lokalnych województwa mazowieckiego. Główna hipoteza, mówiąca o tym, że w systemie wydatkowania środków publicznych jest możliwe przeprowadzenie chociażby wstępnego audytu efektywnościowego w zakresie efektywności kosztowej, zostaje odrzucona. Z przeprowadzonych analiz wynika, iż ogólnodostępne dane (niewymagające występowania o te dane) nie pozwalają na dokonanie nawet wstępnego audytu efektywnościowego w zakresie kosztu jednostkowego realizowanych inwestycji, a jedynie pozwalają na wstępny ogląd relacji nakładów do wyników w obszarze inwestycji prowadzonych w obszarze infrastruktury drogowej. Według Autorów brakuje wielu niezbędnych danych w ogólnodostępnej statystyce publicznej, które umożliwiłyby przeprowadzenie chociażby przeglądowego, wstępnego audytu efektywnościowego w zakresie analizy efektywności kosztowej. W naszej opinii dane te powinny być gromadzone w wystandaryzowanej bazie danych publicznych, aby koszt poszukiwania informacji był jak najmniejszy, a gromadzone informacje miarodajne i dające podstawy do gospodarnego wydatkowania środków z funduszy publicznych. Autorzy niniejszego artykułu zdają sobie sprawę z faktu, iż nie wyczerpali wszystkich czynników zmienności, które wpływają na koszt jednostkowy budowy infrastruktury drogowej, jednakże badanie zawarte w artykule może być pomocne w przeprowadzeniu bardziej pogłębionych badań w przyszłości. Intencją Autorów było również pozostanie na pewnym poziomie ogólności, pozwalającym otworzyć w przyszłości drogę do dyskusji nad zasadnością wydatków publicznych, gdzie to już rolą osób podejmujących decyzje o wydatkach inwestycyjnych byłoby publiczne uzasadnienie adekwatności poniesionych kosztów i ewentualne wyjaśnienie wyższych od wartości średniej kosztów jednostkowych budowy infrastruktury drogowej. Podobne opisy mogą również pojawiać się w przyszłości w bazach danych porównujących koszty tego typu infrastruktury.

Niedostatek i brak ciągłości w zapewnieniu istotnych informacji na temat publicznych inwestycji i projektów wykonywanych w ramach działania sektora publicznego w zakresie kosztu jednostkowego powoduje, iż w dużej mierze samorządy lokalne stanowią „czarne skrzynki”. Z kolei otwarcie nieco mniejszej „czarnej skrzynki”, w postaci konkretnego projektu, jest możliwe jedynie po wnikliwym przeanalizowaniu SIWZ lub umowy podpisanej w ramach zamówienia publicznego, a następnie protokołów zdawczo-odbiorczych i kosztorysów powykonawczych. Można stwierdzić, że pojawia się asymetria informacji zarówno pomiędzy samorządami i wykonawcami, ale również pomiędzy administracją jednostek publicznych a obywatelami, którzy chcieliby uzyskać szczegółowe i porównywalne informacje na temat inwestycji realizowanych przez instytucje publiczne na poziomie samorządowym, zwłaszcza w dłuższym horyzoncie czasowym. 


\section{Literatura}

Andrews R., Entwistle T., 2014, Public Service Efficiency. Reframing the debate, Routledge, Abingdon.

Bartoszewicz A., 2015a, Transformacja audytu wewnętrznego w Polsce-od audytu zgodności do audytu efektywnościowego, Prace Naukowe Uniwersytetu Ekonomicznego we Wrocławiu, 390, s. 36-44.

Bartoszewicz A., 2015b, Performance audit as a tool oriented at the accountability of public finance spending in Poland against the background of UK practices, Zeszyty Teoretyczne Rachunkowości, 84,140 , s. $23-47$.

KPRM, 2011, Analiza-Ocena sposobu wykonania kontroli zarzadczej, Kancelaria Prezesa Rady Ministrów, DKN - 520-1(20) 11 z 10 sierpnia 2011 r.

Modzelewski P., 2009, System zarządzania jakościq a skuteczność i efektywność administracji samorządowej, CeDeWu, Warszawa.

Nita B., 2015, Pomiar wartości ustug publicznych w kontroli zarządczej [w:] K. Winiarska (red.), Kontrola zarzadcza oraz audyt wewnętrzny w teorii i praktyce, Rozprawy i Studia, (CMXLVIII) 874, Uniwersytet Szczeciński, Szczecin, s. 271-282.

Pollitt Ch., Bouckaert G., 2011, Public Management Reform. A Comparative Analysis - New Public Management, Governance, and the Neo-Weberian State, wyd. 3, Oxford University Press, New York.

Strzelecki Z. (red.), 2013, Diagnoza, Trendy rozwojowe Mazowsza, Mazowieckie Biuro Planowania Regionalnego, Warszawa.

Szołno O., 2016, Wybrane aspekty pomiaru efektywności i skuteczności jednostki samorządu terytorialnego, Finanse, Rynki Finansowe, Ubezpieczenia, 84, 6, cz. 1, Lublin, s. 91-99.

Wojtowicz-Żygadło J., Szczygieł L., 2012, Dynamika finansowania inwestycji w wybranych gminach województwa podkarpackiego, Nierówności Społeczne a Wzrost Gospodarczy, 27, s. 123-135.

\section{Strony internetowe}

Ministerstwo Finansów, Departament Audytu Sektora Finansów Publicznych, Audyt efektywnościowy, http://www.mf.gov.pl/ministerstwo-finansow/dzialalnosc/finanse-publiczne/ kontrola-zarzadcza-i-audyt-wewnetrzny/audyt-wewnetrzny-w-sektorze-publicznym/metodyka [dostęp 20.12.17].

Biuletyn Informacji Publicznej Gminy Ciepielów: http://archiwum2015.ciepielow.pl/index2. php?id=menu/przetargi/150310_13 [dostęp 01.02.2018].

Biuletyn Informacji Publicznej Starostwa Powiatowego w Makowie Mazowieckim: http:// www.bip.powiat-makowski.pl/public/?id=93556 [dostęp 02.02.2018]. 
Witryna gminy Sypniewo: http://psimegabajt.home.pl/www.sypniewo.pl/inwestycje-wgminie-sypniewo/395-modernizacja-drog-w-gminie-sypniewo-etap-iii-realizacja-czescietapu-w-technologii-masy-asfaltowej.html [dostęp 02.02.2018].

Witryna gminy Karniewo: http://www.biuletyn.net/ntbin/start.asp?podmiot=karniewo/\&str ona=13\&typ=menu\&menu=35\&id=245\&str=1[dostęp 02.02.2018].

Biuletyn Informacji Publicznej Starostwa Powiatowego w Węgrowie: https://bip.powiatwegrowski.pl/inwestycje/dokumenty/2015.5353/ [dostęp 02.02.2018].

\section{Akty prawne}

Ustawa z dnia 27 sierpnia 2009 r. o finansach publicznych (Dz.U. z 2009 r. nr 157, poz. 1240). 


\section{Załącznik 1}

Tabela 5. Projekty inwestycyjne na terenie wybranych powiatów województwa mazowieckiego w latach 2012-2015

\begin{tabular}{|c|c|c|c|c|c|}
\hline Lp. & $\begin{array}{l}\frac{\pi}{3} \\
\frac{\pi}{3} \\
0\end{array}$ & Nazwa projektu & $\begin{array}{l}\text { Wartość } \\
\text { projektu }\end{array}$ & Gmina & $\begin{array}{l}\text { Wartość dla } \\
\text { powiatu ogółem }\end{array}$ \\
\hline 1. & \multirow{4}{*}{ : } & $\begin{array}{l}\text { Przebudowa-modernizacja drogi } \\
\text { gminnej Gardzienice Kolonia - } \\
\text { Stare Gardzienice - Ciepielów }\end{array}$ & $469163,46 \mathrm{zł}$ & Ciepielów & \multirow[t]{4}{*}{6784503,86 zł } \\
\hline 2. & & $\begin{array}{l}\text { Przebudowa-modernizacja drogi } \\
\text { powiatowej nr 1905W Leszczyny } \\
\text { - Lipsko na odcinku Huta - } \\
\text { Lipsko, dł. 8+480. II etap Huta- } \\
\text { Ratyniec w km 2+850 - 6 + } 550 \mathrm{dł.} \\
3+700 \mathrm{~km}\end{array}$ & $1856933,54 \mathrm{zł}$ & Lipsko & \\
\hline 3. & & $\begin{array}{l}\text { Przebudowa-modernizacja } \\
\text { drogi powiatowej nr } 3536 \mathrm{~W} \\
\text { Odechów - Kowalków - Sienno } \\
\text { - Sarnówek na odcinku długości } \\
7390 \text { mb od km } 25 \text { + } 730 \text { do km } 33 \\
\text { + 120; Sienno - granica powiatu/ } \\
\text { Sarnówek }\end{array}$ & 2762 276,66 zł & Sienno & \\
\hline 4. & & $\begin{array}{l}\text { Przebudowa-modernizacja drogi } \\
\text { powiatowej nr 1906W Czerwona } \\
\text { - Ciepielów na odcinku Bąkowa } \\
\text { - Wielgie w km } 5+000 \text { - 8 + } 700 \\
\text { o długości } 3700 \text { mb. Etap II }\end{array}$ & 1696 130,20 zł & Ciepielów & \\
\hline 5. & \multirow{3}{*}{ 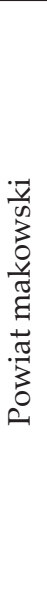 } & $\begin{array}{l}\text { Modernizacja dróg w Gminie } \\
\text { Sypniewo - Etap III Realizacja } \\
\text { części etapu w technologii masy } \\
\text { asfaltowej. }\end{array}$ & 1302 261,86 zł & Sypniewo & \multirow[t]{3}{*}{$9304088,38 \mathrm{zl}$} \\
\hline 6. & & $\begin{array}{l}\text { Przebudowa drogi powiatowej } \\
\text { nr 3238W Przasnysz - Leszno } \\
\text { - Karniewo - Przemiarowo od } \\
\text { km } 16 \text { + } 051 \text { do km } 30 \text { + } 150 \text { wraz } \\
\text { z infrastrukturą towarzyszącą }\end{array}$ & $6009481,90 \mathrm{zł}$ & Karniewo & \\
\hline 7. & & $\begin{array}{l}\text { Przebudowa drogi gminnej nr } \\
210222 \text { W na odcinku o długości } \\
\text { 2,245 km - ulica Mazowiecka , } \\
\text { Przemysłowa i Szkolna }\end{array}$ & 1992344,62 zł & Karniewo & \\
\hline
\end{tabular}




\begin{tabular}{|c|c|c|c|c|c|}
\hline Lp. & $\begin{array}{c}. \pi \\
\sum_{3}^{\pi} \\
0 \\
c\end{array}$ & Nazwa projektu & $\begin{array}{l}\text { Wartość } \\
\text { projektu }\end{array}$ & Gmina & $\begin{array}{l}\text { Wartość dla } \\
\text { powiatu ogółem }\end{array}$ \\
\hline 8. & \multirow{4}{*}{ 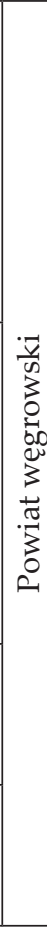 } & $\begin{array}{l}\text { Przebudowa drogi powiatowej } \\
\text { nr 4207W (36108) Paplin - } \\
\text { Sadowne w km } 4+300-10+650 \\
\text { o długości 6,35 km na terenie } \\
\text { gminy Stoczek i w km } 17+870,7 \\
\text { - } 20+591,5 \text { o długości 2,72 km na } \\
\text { terenie gminy Sadowne. }\end{array}$ & $1139398,37 \mathrm{zł}$ & Sadowne & \multirow[t]{4}{*}{$13013280,72 \mathrm{zl}$} \\
\hline 9. & & $\begin{array}{l}\text { Przebudowa drogi powiatowej } \\
\text { nr 4207W (36108) Paplin - } \\
\text { Sadowne w km 4+ } 300-10+650 \\
\text { o długości 6,35 km na terenie } \\
\text { gminy Stoczek i w km } 17+870,7 \\
\text { - 20 + 591,5 o długości 2,72 km na } \\
\text { terenie gminy Sadowne. }\end{array}$ & $1139398,37 \mathrm{zł}$ & Stoczek & \\
\hline 10. & & $\begin{array}{l}\text { Przebudowa drogi gminnej } \\
\text { Gwizdały - Łazy - Brzuza, } \\
\text { Gmina Łochów }\end{array}$ & 8328357,98 zł & Łochów & \\
\hline 11. & & $\begin{array}{l}\text { Przebudowa drogi gminnej } \\
\text { Budziska - Kaliska - Pogorzelec, } \\
\text { Gmina Łochów }\end{array}$ & 2406 126,00 zł & Łochów & \\
\hline 12. & \multirow{3}{*}{ 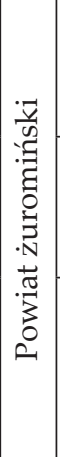 } & $\begin{array}{l}\text { Przebudowa drogi powiatowej } \\
\text { nr 4622W Lutocin - Zimolza - do } \\
\text { drogi nr } 541\end{array}$ & $1217006,91 \mathrm{zł}$ & Bieżuń & \multirow[t]{3}{*}{$5727328,48 \mathrm{zł}$} \\
\hline 13. & & $\begin{array}{l}\text { Przebudowa drogi powiatowej } \\
\text { nr 4622W Lutocin - Zimolza - do } \\
\text { drogi Nr } 541\end{array}$ & $1217006,91 \mathrm{zł}$ & Lutocin & \\
\hline 14. & & $\begin{array}{l}\text { Przebudowa drogi powiatowej } \\
\text { nr 4627W Żuromin - Kliczewo - } \\
\text { Kuczbork od km } 0+720,00 \text { do km } \\
7+790,00\end{array}$ & 3293314,66 zł & Żuromin & \\
\hline
\end{tabular}

Źródło: opracowanie własne na podstawie danych z Krajowego Systemu Informatycznego SIMIK 


\title{
Performance audit in the field of cost efficiency of road infrastructure investments of the Mazovian Voivodship counties
}

\begin{abstract}
The purpose of the paper is to check whether it is possible to carry out a preliminary efficiency audit in the area of cost efficiency of road infrastructure construction undertaken by local governments on the basis of data publicly available, without having to request access to data. A performance audit is a tool that allows measuring, among others, the cost efficiency and making comparisons between local government units in terms of completing certain specific actions. However, carrying out such an audit in full form is usually quite time consuming, complicated and would require an involvement of expert teams. They would have to acquire local government units' internal data on costs of projects implementation. Even the preliminary comparisons of public expenditure on similar or the same ventures can be very useful both in the current work of local governments and for citizens, who are willing to participate in local democratic initiatives. Therefore, it would be reasonable to postulate for the wide availability of public information, not requiring any additional access to data. It would allow to make comparisons between e.g. local government investments. Ensuring comparability when measuring the cost efficiency of individual investments is key to making even a preliminary performance audit. Such an initial audit of unit cost of investments being commonly available to citizens or local government officials can then be treated as a starting point for further, more detailed assessment of the validity of implemented investments and may allow more detailed analysis of effectiveness and efficiency.
\end{abstract}

Key words: performance audit, cost efficiency, local government

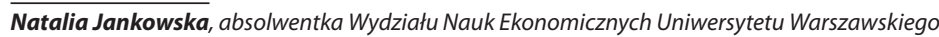

Natalia Jankowska, MA, graduate of the Faculty of Economic Sciences, University of Warsaw

Piotr Modzelewski, dr, Wydział Nauk Ekonomicznych Uniwersytetu Warszawskiego. Jest autorem publikacji z dziedziny ekonomii sektora publicznego oraz sieci współrządzenia; e-mail:pmodzelewski@wne.uw.edu.pl

Piotr Modzelewski, PhD, Faculty of Economic Sciences, University of Warsaw. He has published articles and books on the public sector economics and governance networks; e-mail:pmodzelewski@wne.uw.edu.pl 